\title{
Health effects of probiotics and prebiotics A literature review on human studies
}

\author{
By Henrik Andersson, Nils-Georg Asp, Ake Bruce, \\ Stefan Roos, Torkel Wadström and Agnes E. Wold
}

\begin{abstract}
Human studies on health effects of probiotics and prebiotics were reviewed and evaluated. The main results can be summaries as follows: Certain probiotic lactobacilli may improve lactose digestion and reduce symptoms of lactose intolerance. The effect of probiotics on serum cholesterol is still inconclusive. Animal studies showing triacylglycerol-lowering effects of prebiotics need confirmation in humans. Data on effects of probiotics on constipation are not convincing, whereas inulin has dose-related laxating effect. Effects of a probiotic drink have been reported on symptoms in irritable bowel syndrome, but more studies are needed for firm conclusions. A significant shortening of acute watery rotavirus-included diarrhoea has been demonstrated for two lactobacilli, whereas possible effects on the risk of getting traveller's diarrhoea need further studies. There are promising indications that probiotics could be useful against antibiotic-associated diarrhoea, and a yeast preparation has been shown to reduce the risk of relapsing Clostridium difficile diarrhoea. Promising results from studies on the effect of probiotic products in the treatment of gastritis and inflammatory bowel disease should encourage further studies with pro-, pre- and synbiotic foods. Certain prebiotic oligosaccharides may increase calcium absorption. Probiotics can be regarded as safe although occasional infections have been reported in immunosuppressed patients. Prebiotics such as fructans may cause dose dependent gastrointestinal side-effects.

The documentation of health-promoting effects of probiotic and prebiotic products is rapidly increasing. The food industry that develops pro- and prebiotic products should increase their efforts to develop high quality research and well-designed clinical trials on ordinary food products. This area is of great importance for improving human health.
\end{abstract}

\section{Introduction}

There is increasing evidence that the composition and metabolic effects of the gastrointestinal microflora are of key importance for human health. In addition to promoting normal gastrointestinal functions and protecting from infections, the microflora also seems to exert important effects on systemic metabolism and immune functions.

The definitions of probiotics as "live microbial food ingredients that are beneficial to health", prebiotics as "non-digestible food components that beneficially affect the host by selectively stimulating the growth and/or activity of one or a limited number of bacteria in the colon, that have the potential to improve host health", and synbiotics as "mixtures of probiotics and prebiotics that beneficially affect the host by improving the survival and implantation of live microbial dietary supplements in the gastrointestinal tract" are generally accepted (1).

Microorganisms representing many different genera have been used as probiotics. Most of the efforts have been focused on lactobacilli and bifidobacteria, but also enterococci and the yeast Saccharomyces boulardii have received attention. The term "pre-

Henrik Andersson, Prof., Dept of Clinical Nutrition, Göteborg University, Nils-Georg Asp, Prof., Applied Nutrition and Food Chemistry, Lund University, Åke Bruce, Prof., National Food Administration, Uppsala, Stefan Roos, Dr, Dept of Microbiology, Swedish University of Agricultural Sciences, Uppsala, Torkel Wadström, Prof., Dept of Medical Microbiology and Infectious Diseases, Lund University, Agnes Wold, Assoc Prof., Dept of Clinical Immunology, Göteborg University, Sweden.

Correspondence: Nils-Georg Asp, SNF Swedish Nutrition Foundation, Ideon, SE-223 70 Lund, Sweden. E-mail: asp@snf.ideon.se

Parts of the data in this article was presented at the symposium "Probiotic and prebiotics - scientific evidence in humans as a basis for health claims", 14 15 November 2000, arranged by SNF Swedish Nutrition Foundation. biotics" was coined at a time when the first studies appeared showing that fructo-oligosaccharides - undigestible in the small intestine - could be utilised only by a few bacterial species, notably bifidobacteria, and that feeding such oligosaccharides to experimental animals and man increased the count of bifidobacteria in the intestinal content (2). Much research on oligosaccharides, notably fructo-oligosaccharides and inulin, has been performed recently, including European Commission sponsored projects (3). It should be noted, however, that the stimulation of certain microorganisms by different carbohydrates in vivo does not appear as selective as indicated by in vitro studies Thus, resistant starch and non-starch polysaccharides have also shown a capacity to stimulate bifidobacteria in vivo (4). A question which must be addressed, however, is whether bifidobacteria in thousands really improve host health

\section{Searching the literature for human effect studies}

An ad hoc committee of Swedish scientists, the authors of this article, was formed in the spring 2000 jointly by the Expert Group on Diet and Health of the National Food Administration and the Research Board of SNF Swedish Nutrition Foundation. The task was to review and evaluate human studies on the health effects of probiotics and prebiotics.

The objective was to find all original articles in Medline published until autumn 2000 on human effect studies with proand prebiotics. The words used in the searches were different combinations of the following terms: Lactobacillus, Bifidobacterium, probiotics, different probiotic bacteria or brand names (Lactobacillus GG, Lactobacillus reuteri, Lactobacillus plantarum 299v, Shirota, Lactobacillus acidophilus, LAI, NCFB 1748, Lactococcus lactis L1A, Bb12, Gaio, Lactobacillus rham- 
nosus), prebiotics, inulin, oligofructose, diarrhoea, lactose, blood lipids, cholesterol, irritable bowel syndrome (IBS), cancer, mucositis, inflammatory bowel disease (IBD), Chrohn's disease, inflammation, allergy, safety.

To find additional articles, and also as a control of our search, reference lists of several recent review articles about pro- and prebiotics were used. Furthermore, companies with pro- or prebiotic foods on the Swedish market were asked to send documentation already published or in press. The articles were sorted after the studied effect into the following groups:

- Lactose intolerance $\bullet$ Blood lipids $\bullet$ Hypertension $\bullet$ Constipation

- Irritable Bowel Syndrome (IBS) • Diarrhoea • Gastritis and reflux disease

- Inflammatory Bowel Disease (IBD) • Cancer prevention

- Prebiotics and mineral absorption $\bullet$ Safety

The papers were critically reviewed by the members of the group. The focus of the examination has been studies using probiotic or prebiotic food products, but also studies with lyophilised bacteria have been considered when relevant.

Some studies are listed in Tables 1-4 on pages 66-75. Those references are marked $(*)$ in the following text and in the reference list. Articles are evaluated in the Tables (column 13) as + low quality; ++ medium quality; +++ high quality.

Due to the complexity of effects on immune functions, a more in-depth review on this topic is presented separately (5).

\section{Lactose intolerance}

Lactose is the predominant carbohydrate in milk. The presence of sufficient lactase activity in the small bowel mucosa is necessary for the newborn child to absorb lactose from breast milk. This enzyme is, however, dramatically reduced in adult life in the majority of people. The genes that enable the activity of lactase to remain high prevail mainly in the white Western populations. In Sweden, e.g., low lactase activity is relatively uncommon. It should be noted, however, that lactose malabsorption often occurs without symptoms of lactose intolerance.

Table 1 (on pages $66,68,69$ ) shows studies on lactose intolerance. Several studies have demonstrated that subjects with low intestinal lactase activity absorb lactose from yoghurt $\left(6^{*}, 7^{*}\right)$ or milk containing $L$. acidophilus $\left(8^{*}\right)$ better than from milk. In another study $\left(9^{*}\right)$, however, a four-fold difference in lactase activity between the products had no effect on the digestion and tolerance of lactose. Yoghurt is also better tolerated (gives fewer symptoms) than milk $\left(7^{*}, 10^{*}\right)$. In these studies breath hydrogen concentrations have been measured, as an indication of bacterial fermentation of undigested lactose. The method is only semiquantitative and there is considerable variation in how much hydrogen is absorbed and how much passes with the stools.

Mechanisms: Up to about half of the lactose content can be fermented after 11 days storage $\left(11^{*}\right)$, and microbial lactase activity enters the small bowel with the fermented product. Subjects with lactose intolerance experience more symptoms also after ingesting fructo-oligosaccharides $(12 *)$, indicating increased sensivity to malabsorbed carbohydrates.

Conclusion: Despite the above-mentioned concerns, it seems logical to assume that fermented milk products with specific probiotic lactic acid bacteria improve lactose digestibility and absorption, and may reduce symptoms of lactose intolerance. This conclusion is in agreement with a recent review by Hove et al. (13).

\section{Blood lipids}

\section{Probiotics}

A number of studies have examined the potential of probiotic products to reduce serum cholesterol levels, some are listed in Table 1 (on pages 66-70). Studies without suitable control or placebo groups, lack of run-in periods or administering very large doses of fermented dairy products (700-5000 ml/day) were excluded. An important consideration in the evaluation of the studies is the fact that participation for a single week in a nutritional trial in itself may result in a reduction of serum cholesterol. Furthermore, the analytical precision of serum cholesterol determination has to be considered.

About half a litre of a yoghurt with L. acidophilus $\left(14^{*}, 15^{*}\right)$ or tablets with viable $L$. acidophilus and L. bulgaricus $\left(16^{*}\right)$ did not reduce serum cholesterol according to one randomised controlled trial (RCT) (39 subjects) and two randomised crossover studies ( 219 subjects), but a small effect was seen in two other studies $\left(17^{*}, 18^{*}\right)$. In a further study, yoghurt did not reduce serum lipids (19).

A product containing L. plantarum 299v (ProViva $\left.{ }^{\circledR}\right)$, tested in a parallel study with 30 subjects $\left(20^{*}\right)$ gave a significant reduction in serum cholesterol. However, the test group and the control group had similar cholesterol levels at the end of the study.

A fermented milk product containing Enterococcus faecium and Streptococcus termophilus $\left(\mathrm{GAIO}^{\circledR}\right)$ has been tested in three RCT studies with parallel designs $\left(21^{*}-23 *\right)$ in altogether 214 subjects. The randomisation was not always optimal. A small but significant reduction was found at some time-periods, but no difference was found between the groups after six months in one of the studies $\left(23^{*}\right)$. GAIO ${ }^{\circledR}$ has also been tested in a randomised crossover study $\left(24^{*}\right)$. A reduction in serum cholesterol was found after six weeks.

Mechanisms: The mechanisms whereby probiotics may reduce serum cholesterol are largely unknown. Certain strains of bacteria, however, have the capacity to assimilate cholesterol in vitro. An ileostomy study has shown a reduced absorption of cholesterol from the small bowel after treatment with probiotics $\left(25^{*}\right)$.

Conclusion: The effect of probiotics on serum cholesterol is still inconclusive. More long-term studies are required to document a sustained effect. These conclusions are supported by recent reviews $(26-27)$.

\section{Prebiotics}

Dietary carbohydrates represent a complex group of food components. Dietary oligosaccharides, strictly defined, are composed of two to nine monomers linked together, but inulin is often included in spite of a chain length larger than this. Nondigestible oligosaccharides may act as substrates for the colonic microflora.

Convincing serum lipid-lowering effects of inulin have been demonstrated in animals; attempts to reproduce similar effects in humans, however, have given conflicting results. One reason may be that animals were given much larger doses of inulin than tolerated in humans. Animal studies have identified inhibition of fatty acid synthesis as the major site of action for the triacylglycerid-lowering effect of inulin. This pathway is, however, relatively inactive in humans (28).

Two RCT studies $(29 *, 30 *)$, including altogether 30 subjects, have shown reductions in serum cholesterol and triglycerides with inulin. Moreover, in one small crossover RCT $\left(31^{*}\right)$ on 12 subjects, serum cholesterol and triglycerides were reduced after inulin ingestion. In another crossover RCT in 21 subjects $(32 *)$, a reduction of serum cholesterol was found only relative to the control group. In three crossover RCTs (33*-35*) including 96 subjects, no effect in serum cholesterol and triglycerides was found. In another study there was also no effect on plasma lipids, but a decreased basal hepatic glucose production was found with fructo-oligosaccharides (36*). In a recent double-blind RCT parallel design study and 54 subjects there was a trend for the 
triacylglycerol level to be lower after 8 weeks on $10 \mathrm{~g}$ of inulin $\left(37^{*}\right)$. Ileostomy studies have not shown any increase in cholesterol or bile salt excretion from the small bowel by prebiotic treatment $\left(38^{*}\right)$, i.e. addition of $17 \mathrm{~g}$ of inulin or oligofructose to the diet.

Conclusion: No convincing serum cholesterol-lowering effect can be ascribed to inulin or oligo-fructose from the present studies. The effect on the triacylglycerol level in man remains to be elucidated further.

\section{Hypertension}

Two Japanese studies have been published on the effect of fermented milk on blood pressure (Table 1, on pages 67,68,70). In the first study, Lactobacillus helveticus and Saccaharomyces cerevisiae were used (39*), in the second one L. casei TMC 0409 and Streptococcus thermophilus TMC 1543 were investigated $\left(40^{*}\right)$. In both studies significant reductions in systolic blood pressure were found, and in one study (39*), effects on diastolic blood pressure were also noted. It was suggested that the effect could be due to the formation of certain tripeptides that are inhibitors of ACE (Angio-tension-converting enzyme).

Further studies are needed to test the effect of these peptides and to establish the conditions for their formation.

\section{Constipation}

\section{Probiotics}

Constipation means complaints with bowel evacuations, low bowel emptying frequency and a slow transit through the large bowel. Based on early reports, different fermented milk products have been claimed to alleviate constipation. Such self-reported information, however, is difficult to evaluate.

Two hundred $\mathrm{ml}$ of a L. rhamnosus GG fermented whey drink $\left(41^{*}\right)$ did not change bowel movement frequency or hardness of stools in a small placebo-controlled study. Similar findings were made with a $L$. rhamnosus $\mathrm{GG}$ yoghurt (42). In another study the effect of milk fermented by $L$. acidophilus on constipation in elderly subjects was difficult to evaluate (43*).

Conclusion: The available data on effects on constipation of probiotics are not convincing. Further studies are needed to substantiate such an effect.

\section{Prebiotics \\ Dietary fibre increases the faecal bulk by two mechanisms: incompletely fermented types of fibre bind water throughout the gastrointestinal tract, whereas readily fermented types of fibre contribute by increasing the microbial mass (44). Since oligo- sacharides are completely fermented, their bulking effect would be expected to occur through an increased microbial mass. \\ Table 3, (page 74) lists three studies $\left(45^{*}-47^{*}\right)$ in which the effect of fructooligosaccharides on faecal weight in humans has been measured. The quite limited data indicate an increase in faecal wet weight of around or somewhat more than $1 \mathrm{~g} / \mathrm{g}$ ingested oligofructose and $1.5-2 \mathrm{~g} / \mathrm{g}$ ingested inulin. These figures are similar to those reported for pectin (1.2) but con- siderably lower than for wheat bran (around 5) (44). In a study on elderly constipated patients inulin reduced functional constipa- tion and increased stool frequency (48).}

Conclusion: Inulin and fructooligosaccharides seem to have dose-related laxating effects.

\section{Irritable bowel syndrome \\ Probiotics}

Irritable bowel syndrome (IBS) is a very common gastrointestinal disorder, and is often the most frequent diagnosis at a gastroenterologist's clinic. Typical symptoms reported are flatulence, variations between diarrhoea (not in the night) and constipation, and abdominal pains.

Different factors are associated with the condition, e.g. food intake, malabsorption and psychosomatic influences. These factors can exert an effect on the motor function of the gastrointestinal tract. Generally, patients with IBS report pain with a lesser degree of abdominal distention than others. It is always difficult to evaluate self-reported symptoms particularly in a condition with psychosomatic influences like IBS.

In a very carefully performed double-blind RCT study on 61 subjects with IBS, no difference in tolerance was seen with unfermented milk containing L. acidophilus compared to ordinary milk $\left(49^{*}\right)$.

A rose-hip drink with $L$. plantarum 299v (400 ml/day) was tested in two RCTs with parallel designs. In one of the studies (40 patients), improvement of symptoms was significantly greater in the study group than in the control group $(50 *)$. In the other study (52 patients), flatulence was reduced in the test group compared with the placebo group $\left(51^{*}\right)$. Abdominal pain was reduced in both groups, even though the reduction was more rapid and pronounced in the test group. There was no major change in gas bloating.

Conclusion: An effect on some symptoms in IBS is reported with L. plantarum 299v. More controlled studies are needed for firm conclusions on the importance of probiotics in the treatment of IBS.

\section{Diarrhoea}

The effect of probiotics on diarrhoeal disease of varying ætiology has been quite extensively studied and clinical trials have recently been reviewed $(52,53)$. We will concentrate here on four conditions that have been subject to human studies using milkbased products - acute watery diarrhoea in children, travellers' diarrhoea, antibiotic-associated diarrhoea and relapsing diarrhoea due to Clostridium difficile infection.

\section{Acute watery diarrhoea in children}

Acute diarrhoea in children is mainly caused by rotavirus. $L$. rhamnosus strain GG is the probiotic strain which has been most extensively studied to treat this condition. Both milk products fermented with this bacterium and freeze-dried bacteria have been shown to shorten acute diarrhoea, especially when caused by rotavirus $\left(54^{*}, 55^{*}\right.$ ) (Table 2 , on pages $71-73$ ). Since acute diarrhoea is self-limiting, seldom lasting for more than a week, the therapeutic effect is small. Thus, the duration of diarrhoea is usually shortened by approximately 1 day (Table 2, on pages 71 73). However, the effect is reasonably well proven and has also been replicated in a number of other studies (for a review see 52,53).

Two studies have investigated the effect of Lactobacillus reuteri SD2112 on acute diarrhoea in childhood. Both demonstrate an effect in the same order of magitude as reported for $L$. rhamnosus GG $\left(56^{*}, 57^{*}\right)$, (Table 2 , on pages $71-73$ ).

It should be noted that only one of the above mentioned studies $\left(54^{*}\right)$ gives data on the extent of breast-feeding in the different study groups. Since breast-feeding effectively counteracts diarrhoea, it is important to control for this factor.

Conclusion: A significant shortening of acute watery rotavirusrelated diarrhoea in children has been demonstrated for both $L$. rhamnosus $\mathrm{GG}$ and $L$. reuteri $\mathrm{SD} 2112$.

\section{Travellers' diarrhoea}

A few placebo-controlled studies have all failed to show effective prevention of infectious diarrhoea in adults (53). These 
studies were performed with freeze-dried probiotic preparations, and no data have been published on the possible effects of probiotic food products in this respect.

Conclusion: More controlled trials with probiotic foods are needed and justified since some probiotics have shown an effect on diarrhoea in children.

\section{Antibiotic-associated diarrhoea}

Treatment with antibiotics results in diarrhoea and abdominal discomfort in a variable fraction of patients, depending on the age group and the antibiotic used. In most cases, the cause of the diarrhoea is unknown, but a varying proportion of the cases are caused by Clostridium difficile. This toxin-producing species is not uncommon in the normal intestinal microflora, but is usually present only in low numbers and without causing any harm. After treatment with certain antibiotics, the lack of competition from other microbes in the normal intestinal flora permits $C$. difficile to reach high numbers. The $C$. difficile toxins may cause anything from mild diarrhoea, which can be cured simply by terminating the antibiotic treatment, to the life-threatening disease pseudomembranous colitis.

Table 2 (on pages 71-74) includes four randomised placebocontrolled studies $\left(58^{*}-61 *\right)$ that investigate the effect of probiotic intake on gastrointestinal side effects of antibiotic treatment. A yoghurt containing bifidobacteria was shown to quite effectively reduce abdominal complaints in volunteers consuming erythromycin for 3 days $\left(58^{*}\right)$. In another study, using parallel groups, no clinical effects of yoghurt with bifidobacteria and Lactobacillus acidophilus were noted, but on the other hand, inulin was added to the yoghurt, which in itself may cause loose stools and abdominal discomfort $\left(59^{*}\right)$. An interesting observation was that $C$. difficile was isolated from stool cultures of six of ten in the control group, but in only one of nine volunteers in the group given the active yoghurt preparation $(\mathrm{p}=0.08)$.

The effect of Lactobacillus rhamnosus GG was studied in volunteers taking erythromycin for 7 days $\left(60^{*}\right)$. The data are poorly described in the paper, but according to the authors the volunteers given placebo experienced diarrhoea for 8 days and the volunteers given lactobacilli had diarrhoea only for 2 days.

Arvola et al. studied the potential of L. rhamnosus GG to reduce the risk of antibiotic-associated diarrhoea in a clinical setting $(61 *)$. Children receiving antibiotics against respiratory tract infection (amoxicillin being most frequent, followed by penicillin) were randomised to placebo or capsules with lactobacilli. The drop-out rate was quite high and the therapeutic effect was of borderline significance.

Conclusion: Despite the individual drawbacks of the studies cited above, they offer promising indications that probiotics could be useful against side effects of antibiotic treatment. Larger and better controlled studies with probiotic foods are urgently needed.

\section{Relapsing Clostridium difficile infection}

Severe $C$. difficile infection is treated with antibiotics active against anaerobic bacteria (vancomycin or metronidazol). The treatment is successful in most cases, but in some $20 \%$ of patients, $C$. difficile is not eradicated and the patient is plagued by recurrent episodes of diarrhoea. This condition, termed relapsing $C$. difficile infection, is difficult to treat and new therapeutic alternatives are needed in this patient group.

Only a single placebo-controlled clinical study has been reported on the effects of probiotics on relapsing $C$. difficileinduced disease. This study utilised the yeast Saccharomyces boulardii $(62 *)$ (Table 2, on pages $71,72,74)$. The study was designed, performed and evaluated in an excellent manner, which permits conclusions to be drawn with a high degree of certainty. By adding $S$. boulardii to the metronidazol or vancomycin treatment aiming to eradicate $C$. difficile, the risk of the patient relapsing was halved.

L. rhamnosus GG has only been evaluated in open trials against relapsing $C$. difficile disease. Five adult patients were treated with $10^{10} \mathrm{CFU} /$ day, and four experienced no further relapses (63). Four children who were treated with $L$. rhamnosus GG became asymptomatic (64).

Bennet et al. (65*) studied a large series of adult patients, some of whom were referred to a specialist clinician because of relapsing $C$. difficile infection. Some of the patients were residents in a nursing home consistently plagued with $C$. difficile disease. The patients were given capsules containing $L$. rhamnosus $\mathrm{GG}$ without addition of antibiotics $\left(65^{*}\right)$ (Table 2 , on pages $71,72,74)$. After a single treatment period which lasted for 10-21 days, $84 \%$ of the patients did not relapse within the follow-up period, which was 1 month for the ambulatory patients and 2 months for the nursing home patients. Since the trial was open, we do not know what the relapse rate would have been, had the patients not been given probiotics. However, it is reasonable to believe that half of the patients would have relapsed during that period without treatment, based on figures from the large multicentre study of McFarland (62*). The study thus indicates that $L$. rhamnosus could be a promising candidate for treating relapsing $C$. difficile infection.

Conclusion: One probiotic agent, S. boulardii, has been convincingly shown to reduce the risk of relapsing with $C$. difficile diarrhoea. For other microorganisms, we have only data from open trials. Since this is a very important potential application for probiotics, controlled studies with probiotic foods should be carried out.

\section{Potential mechanisms involved in control of diarrhoea} It was originally assumed that the ability of probiotic bacteria to shorten diarrhoea was dependent on their ability to colonise the intestine and "alter the microbial balance" in such a way that the pathogen would be eliminated. Specific probiotic strains such as L. plantarum 299 and 299v (66), L. rhamnosus 271 (66) and $L$. rhamnosus GG (67) have been proven to colonise human volunteers. This might relate to the fact that these lactobacillus species are prevalent on the normal human intestinal mucosa (68). However, some probiotic bacteria do not colonise, but are eliminated at a rate similar to ingested inert particles $(69,70)$. Nevertheless, probiotics that are not likely to colonise can still reduce diarrhoea. This is most strikingly demonstrated for the yeast $S$. boulardii that has been unequivocally proven effective against $C$. difficile-induced symptoms without being able to colonise the intestine. But also bifidobacteria seem to reduce diarrhoea caused by antibiotic treatment $\left(58^{*}\right)$ without being able to colonise the individual $\left(59^{*}\right)$

Another proposed effect has been that the probiotic induces an enhanced immune response against the microorganism causing the diarrhoea and that this leads to earlier resolution of the diarrhoeal disease. This has been proposed to be the mechanism of the effect of $L$. rhamnosus $\mathrm{GG}$ against rotavirus diarrhoea (71). But differences in antibody titres between patients fed $L$. rhamnosus $\mathrm{GG}$ and controls appear only in the convalescence phase (71), when the virus has long since disappeared. Moreover, no differences in antibody titres were seen between patients fed $L$. reuteri and controls (56*), although this organism seemed equally as efficient as $L$. rhamnosus in controlling the diarrhoea $\left(56^{*}, 57^{*}\right)$.

The mechanism by which probiotic intake reduces diarrhoea 
must therefore be regarded as entirely unknown. Potential mechanisms include an influence on the enteric nervous system and/or immune system leading to the production of neuropeptides (72), cytokines (73) or hormones (74) that reduce the secretion of water and electrolytes across the intestinal epithelium.

In the case of $C$. difficile diarrhoea, the probiotic might act on the host, reducing the secretory response to the clostridial toxin, as outlined above. It is also possible that the probiotic changes the milieu in the intestine, leading to reduced toxin production by the clostridiae, since the toxin production of these organisms is strictly controlled by environmental conditions (75).

\section{Gastritis and reflux disease}

L. acidophilus strain LA1 was grown in milk and tested against Helicobacter pylori induced gastritis in a clinical study with promising effect. Suppression of the infection was determined by a standard breath test (76). However, the effect was reversible, as also seen in a Japanese study with a probiotic Clostridium preparation. More recently Canducci et al. (77) tested L. rhamnosus GG strain together with antibiotic therapy with fewer gastrointestinal side effects in the probiotic group, suggesting that probiotics could be designed to improve $H$. pylori treatment outcome and prevent side effects such as symptoms of increased acid reflux post-treatment.

\section{Inflammatory bowel disease}

Inflammatory bowel disease (IBD) may be caused or aggravated by alterations in the microbial flora. Thus the distal ileum and colon are most frequently affected by the inflammatory process in patients with IBD, sites which harbour the largest populations of intestinal bacteria. Early studies with probiotic lactic acid bacteria (LAB) (L. reuteri and L. plantarum 299v) strains showed protective effect in chemically induced colitis in rodents. More recently, studies in humans with ulcerative colitis given mesalazine or capsules, containing a well defined $E$. coli strain, showed no diffeence in relapse rates, but unfortunately no placebo group was included.

One placebo-controlled clinical study was performed recently on patients with pouchitis, a common long-term inflammation of the ileal reservoir created after surgical removal of the colon. Patients on this therapy for 9 months showed few relapses $(15 \%)$ compared to $100 \%$ in the control group. This study further supports the potential role of probitics food products in IBD therapy and prophylaxis (78-80).

Recently, a complex probiotic preparation containing 200 billion per gram of viable freeze-dried bacteria of four LAB strains, three bifidobacteria and one strain of Streptococcus salivarius, subspecies thermophilus, was tested in a clinical trial in patients showing allergy or intolerance of other origin to classical therapy with mesalamine or sulphasalazine (78-80). The treated group showed reduced faecal $\mathrm{pH}$ and remained in remission. In another study, the same complex preparation (VSL x 3 from Yovis, Sigma Tau Pomezia, Italy) showed good effects on patients with chronic relapsing pouchitis combined with increased LAB and $S$. salivarius counts in pouch contents (80).

Mechanisms: Recent observations in murine knockout models for IBD suggest that an immunlogical up-regulated Th1 cell response and breaking of the mucosal tolerance against the indigenous gut microflora are involved in various forms of IBD (79). Other recent observations indicate that patients with ulcerative colitis lack a normal indigenous LAB microflora in colonic biopsies, also supporting the hypothesis that IBD may be prevented by replacement by an appropriate pro- and prebiotic food based regime.
Conclusions: Well-designed large-scale randomised placebocontrolled clinical trials of different pro- and prebiotics preparations versus standard therapy in IBD and pouchitis should now be undertaken. Promising results of probiotic preparations have been reported and should encourage studies with pro-, pre-, and synbiotic foods.

\section{Cancer prevention}

Various enzymes in the gut microflora modify ingested foreign compounds such as nitro aromatics, azocompounds and nitrate, which can be metabolised to genotoxic and carcinogenic substances by enzymes of the anaerobic microflora of the colon (81). A number of studies have shown that diet and antibiotics can change the microflora-associated characteristics, and nondigestible oligosaccharides (NDOs) suppress carcinogen metabolising enzyme activities in rats (82). Furthermore, LAB and bifidobacteria have generally low activities of enzymes involved in carcinogen production. Supplementation of galactooligosaccharides (GOS) and the synthetic disaccharide lactulose have been shown to decrease faecal $\beta$-glucuronidases and increase lactobacill counts in rats $(83,84)$.

However, despite these experimental facts, evidence is still missing from human studies that $\mathrm{LAB}$ and prebiotics such as GOS and FOS (galactose- and fructooligosaccharides) would decrease the risk of colon cancer development in humans. Two early studies in Japan on the treatment of human urinary bladder cancer by L. casei (Yakult) indicates that immunomodulatory effects of LAB and bifidobacteria cells may be used in the future to prevent and treat cancer of the human colon $(84,85)$. However, further studies in this direction should be performed.

Two studies with probiotic milk products in patients undergoing radiotherapy for pelvic malignancies indicate that such products should be further tested to prevent therapy-related diarrhoea and clinical bowel discomfort symptoms $(86,87)$.

Conclusion: Further identification and validation of biomarkers for risk of cancer is a prerequisit for further studies, to evaluate the potential of probiotics and prebiotics in man in relation to cancer.

\section{Prebiotics - mineral absorption}

Experiments with rats have shown that non-digestible oligosaccharides like inulin and oligofructose can increase the absorption and retention of minerals such as calcium, magnesium, iron and zink (e.g. 88,89). Similar results have previously been obtained with pectin. From animal studies it is postulated that this enhanced absorption occurs in the colon, and that the mechanism is related to increased solubility of calcium due to lower $\mathrm{pH}$ of the colonic content induced by fermentation of oligosaccharides.

Three human studies (Table 4, page 75) testing this hypothesis have been published so far. In the first one Coudray et al. (90*) used conventional balance technique during 28-day periods. Forty grams of inulin (successively introduced to obtain the maximum dose during the last 12 days of the period) increased the apparent absorption of calcium from 21 to $34 \%$ and the retention from -10 to $+92 \mathrm{mg} /$ day, i.e. by about $100 \mathrm{mg} /$ day. A similar improvement in calcium balance was obtained with sugar beet fibre.

When using a double stable isotope technique, van den Heuvel et al. $\left(91^{*}\right)$ did not find any effect on calcium or iron absorption after 9 days with $15 \mathrm{~g}$ oligofructose/day in young (20-26 y) male subjects. Absorption was measured during $24 \mathrm{~h}$. In a subsequent study (92*) the group used the same technique in boys (14-16 y), but extended the measurement period to $36 \mathrm{~h}$. An increase in true fractional calcium absorption by $11 \%$ was obtained. 
It should be noted that calcium balance studies need long study periods and a rigorous control of diets. The negative study is consistent with the hypothesis that increased absorption occurs in the colon, since the calcium absorption was measured during a 24 h-period only. This is also consistent with an ileostomy study by Ellegård et al. (38*) in which oligofructose did not alter the small-intestinal absorption of calcium or other minerals.

Conclusion: Two human short-term studies have confirmed data from animal experiments that oligofructose may increase calcium absorption.

Long-term studies with well-controlled diets are needed to evaluate the potential of prebiotics to contribute to increased bone health.

\section{Safety aspects \\ Probiotics}

Lactic acid bacteria (LAB) are Gram-positive anaerobic aerotolerant non-spore-forming rods and cocci that are indigenous inhabitants of the human gastrointestinal tract, vagina and human skin.

LAB have been isolated in immunosuppressed patients with subacute endocarditis, with increasing frequency in recent years. This indicates that LAB can translocate to the blood in cancer and leukaemia patients or in immunosuppression (93). The findings that most clinical LAB isolates belonges to the rhamnosus-casei group, stimulated an extensive study in Finland recently. The $L$. rhamnosus GG strain could not be isolated from any of the LABpositive blood cultures (94). This study and the development of animal models such as cytostatic-treated mice, orally fed with LAB strains and other microbes, allow us to simulate the situation in immunosuppressed human cancer patients and new syndromes such as HIV/AIDS $(95,96)$. Such studies should be encouraged for "old and new" milk and other food-based probiotic products with equivalent doses of lactobacilli given daily. Such safety studies are naturally also needed for other biotherapy-based regimens such as multi-strain based probiotics against inflammatory bowel disease and pouchitis $(79,80)$.

Conclusion: As concluded in the review by Marteau (93), infections with lactobacilli occur occasionally in immunosuppressed patients, and this safety aspect should be monitored.

\section{Prebiotics}

The Nordic Working Group on Food Toxicology and Risk Evaluation (NNT), which is a body under the Nordic Council of Ministers, recently performed a safety evaluation of fructans, as a project within the Nordic Committee of Senior Officials for Food Issues, co-ordinating Nordic work in the field of foods. Within that committee a Nordic project group was established to draft a manuscript that was finally approved by NNT in September 1999 (97). The group reviewed available toxicity studies in experimental animals as well as reports on adverse effects in humans.

The report concluded, mainly from the 1-3-week human studies available, that adverse effects like flatulence, abdominal pain, bloating, cramps and diarrhoea are unlikely to occur with consumption of $20 \mathrm{~g}$ fructooligosaccharides (FOS)/day or less for a person weighting $60 \mathrm{~kg}$. This is in agreement with a previous evaluation by the Scientific Committee on Food of the European Commission (SCF), which defined the no-effect-level for laxative effect in humans to $0.3-0.4 \mathrm{~g} / \mathrm{kg}$ body-weight.

Conclusion: The overall conclusion of this safety evaluation of oligosaccharides was: "FOS had no significant effects, other than gastrointestinal symptoms at doses 5-40 times higher than the no-effect-level for laxative effects in humans". Although not sufficiently studied, there is a tendency that inulin is better tolerated than FOS.

\section{The scientific documentation of probiotic products sold in Sweden in 2000}

As part of the investigation of pro- and prebiotics, the scientific documentation of products on the Swedish market in 2000 was scrutinized. The four relevant Swedish producers and one Finnish producer of probiotic products were contacted by the National Food Administration and asked to provide their scientific documentation, focusing on human studies of healthpromoting effects and clinical studies evaluating the usefulness of their products in the treatment or prevention of specific diseases or clinical conditions.

It was emphasised that the focus of this literature survey was on original studies of the product(s) in question. In addition to the studies already identified in our literature search, one study (50) on effects in subjects with irritable bowel syndrome was provided with "submitted" status. The published and ongoing human effect studies on probiotic products need further evaluation as a basis for product-specific physiological claims or health claims. Such evaluations have to be made in relation to the type of claims intended to be used and the target group(s) for the different products.

At present, two products have been classified by the Medicinal Products Agency as "natural remedies" with the indication "traditionally used for the normalization of intestinal flora when temporary gastrointestinal disturbances, e.g. in mild diarrhoea and constipation". It should be noted, however, that the classification as natural remedies has been made on "traditional use" and not based on any evaluation of the product-specific documentation of the products.

Classification as Medical Foods would seem relevant when the product is used as part of a specific medical treatment, e.g. to prevent or treat diarrhoea associated with the use of antibiotics, or as a complication to, for instance, radiological treatment.

\section{Final comments}

The main aim of a clinical trial is to evaluate the benefits and risks ascribed to a treatment. The validity is ensured by using a control group for comparison or using a crossover technique. Randomisation and double blinding are necessary.

In the present survey we found the studies to vary greatly in quality, from large-scale carefully designed trials to small studies with several flaws in the design or conclusions. If health claims are to be made for probiotics, strict requirements have to be made concerning the quality of study design.

The food industry that develops pro- and prebiotic products should increase their efforts to develop high quality research and well-designed clinical trials on ordinary food products. This area is of great importance for improving human health.

\section{REFERENCES}

*References listed in Tables (pages 66-75)

1. Diplock AT, Aggett PJ, Ashwell M, Bornet F, Fern EB, Roberfroid MB Scientific concepts of functional foods in Europe: Consensus document. B J Nutr 1999;81 Suppl. 1:S1-S27.

2. Gibson GR, Roberfroid MB: Dietary modulation of the human colonic microbiota:introducing the concept of prebiotics. J Nutr 1995;125:1401-12.

3. Van Loo J et al: Functional food properties of non-digestible oligosaccharides: a consensus report from the ENDO project. Brit J Nutr 1999;81:121-2.

4. Conway P: Prebiotics and human health: The state-of-the-art and future perspectives. Scand J Nutr 2001;45:13-21

5. Wold A: Immune effects of probiotics. Scand J Nutr 2001;45:76-85

6.* Mustapha A, Jiang T, Savaiano DA: Improvement of lactose digestion by humans following ingestion of unfermented acidophilus milk: influence of bilesensitivity, lactose transport, and acid tolerance of lactobacillus acidophilus. J Dairy Sci 1997;80:1537-45.

7.* Montes RG, Bayless TM, Saavedra JM, Perman JA: Effect of milks 
inoculatedwith Lactobacillus acidophilus or a yogurt starter culture in lactose-maldigestingchildren. J Dairy Sci 1995;78:1657-64

8.* Lin MY, Savaiano D, Harladner S: Influence of non-fermented dairy products bacterial starter cultures in lactase maldigestion in humans. J Dairy Sci 1991,74:87-95

9.* Vesa TH, Marteau P, Zidi S, Briet F, Pochart P, Rambaud JC: Digestion and tolerance of lactose from yoghurt and different semi- solid fermented dairy products containing Lactobacillus acidophilus and bifidobacteria in lactose maldigesters--is bacterial lactase important? Eur J Clin Nutr 1996;50:730-3.

10. *Shermak MA, Saavedra JM, Jackson TL, Huang SS, Bayless TM, Perman JA: Effect of yogurt on symptoms and kinetics of hydrogen production in lactose-malabsorbing children. Am J Clin Nutr 1995;62:1003-6.

11.*Alm L: Effect of fermentation on lactose, glucose, and galactose content in milk and suitability of fermented milk products for lactose intolerant individuals. J Dairy Sci 1982;65:346-52.

12.*Teuri U, Vapaatalo H, Korpela R: Fructooligosaccharides and lactulose causemore symptoms in lactose maldigesters and subjects with pseudohypolactasia than in control lactose digesters. Am J Clin Nutr 2000;71:600-2.

13. Hove.H, Norgaard H, Brobeck Mortensen P: Lactic acid bacteria and the human gastrointestinal tract. Europ J Clin Nutr 1999;53:339-50.

14.*de Roos NM, Schouten G, Katan MB: Yoghurt enriched with Lactobacillus acidophilus does not lower blood lipids in healthy men and women with normal to borderline high serum cholesterol levels. EJCN 1999;53:277-80.

15.*Massey LK: Effect of chanching milk and yogurt consumption on human nutrient intake and serum lipoproteins. J Dairy Sci 1984; 67:255-62.

16. *Lin SY, Ayres JW, Winkler W, Sandine WE: Lactobacillus effects on cholesterol: In vitro and in vivo results. J Dairy Sc 1989;72: 2885-99.

17. $*$ Schaafsma G, Meuling WJ, van Dokkum W, Bouley C: Effects of a milk product, fermented by Lactobacillus acidophilus and with fructo-oligosaccharides added,on blood lipids in male volunteers, J Clin Nutr 1998:52:436-40.

18. Anderson JW, Gilliland SE: Effect of fermented milk (yogurt) containing Lactobacillus acidophilus $\mathrm{L1}$ on serum cholesterol in hypercholesterolemic humans. J Am Coll Nutr 1999;18:43-50

19. McNamara DJ, Lowell AE, Sabo JE: Effect of yoghurt intake on plasma lipid and lipoprotein levels in normolipidaemic subjects. Atheriosclerosis 1989;79:167-81.

20.*Bukowska H, Pieczul-Mroz J, Jastrzebska M, Chelstowski K, Naruszewicz $\mathrm{M}$ : Decrease in fibrinogen and LDL-cholesterol levels upon supplementation of diet with Lactobacillus plantarum in subjects with moderately elevated cholesterol. Atherosclerosis 1998;137:437-8.

21.*Agerholm-Larsen L, Raben A, Haulrik N, Hansen AS, Manders M, Astrup A: Effect of 8 week intake of probiotic milk products on risk factors for cardiovascular diseases. Eur J Clin Nutr 2000;54:288-97.

22.*Agerbaek M, Gerdes LU, Richelsen B: Hypocholesterolaemic effect of a new fermented milk product in healthy middle-aged men. Eur J Clin Nutr 1995;49:346-52.

23.*Richelsen B, Kristensen K, Pedersen SB: Long-term (6 months) effect of a new fermented milk product on the level of plasma lipoproteins - a placebocontrolled and double-blind study. Eur J Clin Nutr 1996:50:811-5.

24. ${ }^{*}$ Bertolami MC, Faludi AA, Batlouni M: Evaluation of the effects of a new fermented milk product (Gaio) on primary hypercholesterolemia. Eur J Clin Nutr 1999;53:97-101.

25* Andersson H, Bosaeus I, Ellegard L, Grahn E, Tidehag P, Hallmans G, et al: Effects of low-fat milk and fermented low-fat milk on cholesterol absorption and excretion in ileostomy subjects. Eur J Clin Nutr 1995; 49:274-81.

26. Taylor GRJ. and Williams CM:Effects of probiotics and prebiotics on blood lipids Brit J Nutr 1998;80:S225-S230.

27. de Rose NM and Katan MB: Effects of probiotic bacteria on diarrhoea, lipid metabolism, and carcinogenesis: a review of papers published between 1988 and 1998. Am J Clin Nutr 2000;71:405-11.

28. Delzenne NM, Williams CM: Actions of non-digestible carbohydrates on serum lipids in humans and animals. In: Gibson GR, Roberfroid MB (eds) Colonic Microbiota, Nutrition and Health. Kluwer Academic Publishers, Dordrecht/Boston/London, 1999;pp213-31.

29. *amashita K, Kawai K, Itakura M: Effects of fructo-oligosaccharides on blood glucose and serum lipids in diabetic subjects. Nutr Res 1984:4:961-6.

30 * Brighenti F, Casiraghi MC, Canzi E, Ferrari A: Effect of consumption of a ready-to-eat breakfast cereal containing inulin on the intestinal milieu and blood lipids in healthy male volunteers. Eur J Clin Nutr 1999;53:726-33.

31.*Canzi E, Brighenti F, Casiraghi MC, Del Puppo E, Ferari A: Prolonged consumption of inulin in ready-to-eat breakfast cereals: Effects on intestinal ecosystem, bowel habits and lipid metabolism. Cost 92. (Abstract)

32.*Davidson MH, Maki KC, Synecki C, Torri SA, Drennan KB: Effects of dietary inulin on serum lipids in men and women with hypercholesterolemia. Nutr Res 1998;18:503-17.

33. *Pedersen A, Sandstrom B, Van Amelsvoort JM: The effect of ingestion of inulin on blood lipids and gastrointestinal symptoms in healthy females. $\mathrm{Br}$ J Nutr 1997;78:215-22.

34.*Alles MS, de Roos NM, Bakx JC, van de Lisdonk E, Zock PL, Hautvast GA: Consumption of fructooligosaccharides does not favorably affect blood glucose and serum lipid concentrations in patients with type 2 diabetes. Am J Clin Nutr 1999;69:64-9.

35.*van Dokkum W, Wezendonk B, Srikumar TS, van den Heuvel EG: Effect of nondigestible oligosaccharides on large-bowel functions, blood lipid concentrations and glucose absorption in young healthy male subjects. Eur J Clin Nutr 1999;53:1-7.

36. Luo J, Rizkalla SW, Alamowitch C, Boussairi A, Blayo A, Barry J-L, Laffitte A,Guyon F, Bornet FRJ, Slama G: Chronic consumption of shortchain fructooligosaccharides by healthy subjects decreased basal hepatic glucoseproduction but had no effect on insulin-stimulated glucose metabolism 1-3. Am J Clin Nutr 1996;63:939-45

37.*Jackson KG, Taylor GR, Clohessy AM, Williams CM: The effect of the daily intake of inulin on fasting lipid and glucose concentrations in middleaged menand women. Br J Nutr 1999 ;82:23-30.

38. Ellegård L, Andersson H, Bosaeus I: Inulin and oligofructose do not influence the absorption of cholesterol, or the excretion of cholesterol, $\mathrm{Ca}$, $\mathrm{Mg}, \mathrm{Zn}, \mathrm{Fe}$, or bile acids but increases energy excretion in ileostomy subjects. Eur J Clin Nutr 1997;51:1-5.

39. *Hata Y, Yamamoto M, Ohni M, Nakajima K, Nakamura Y, Takano T: A placebo-controlled study of the effect of sour milk on blood pressure in hypertensive subjects. J Clin Nutr 1996;64:767-71.

40.*Kawase M: Effect of administration of fermented milk containing whey protein concentrate to rats and healthy men on serum lipids and blood pressure. J Dairy Sci 2000;83:255-62.

41.*Ling WH, Hänninen O, Mykkänen H, Heikura M, Salminen S, Von Wright A: Colonization and fecal enzyme activities after oral Lactobacillus GG administration in elderly nursing home residents. Ann Nutr Metab 1992; 36:162-6.

42. Benno Y. et al: Effects of Lactobacillus GG yoghurt on human intestinal microecology in Japanese subjects. Nutrition Today Supplement 1996; 331:9S-11S.

43.*Alm L, Humble D, Ryd Kjellen E, Setterberg G: The effect of acidophilus milk in the treatment of constipation in hospitalised geriatric patients. In: Nutr and the intestinal flora. XV Symp Swedish Nutrition Foundation Stockholm: Almqvist \& Wiksell International; 1983;pp131-8.

44. Cummings JH: The effect of dietary fiber on fecal weight and composition In: Spiller GA, ed. CRC Handbook of dietary fibre in human nutrition, 2nd ed. Boca Raton, FL:CRC 1993;263-349.

45. *Gibson GR, Beatty ER, Wang X, Cummings JH: Selective stimulation of bifidobacteria in the human colon by oligofructose and inulin. Gastroenterology 1995;108:975-82.

46.*Alles MS, Hautvast JG, Nagengast FM, Hartemink R, Van Laere KM, Jansen JB. Fate of fructo-oligosaccharides in the human intestine. Br J Nutr 1996; $76: 211-21$

47. *Castiglia-Delavaud C, Verdier E, Besle JM, Vernet J, Boirie Y, Beaufrere B et al. Net energy value of non-starch polysaccharide isolates (sugar beet fibre and commercial inulin) and their impact on nutrient digestive utilization in healthy human subjects. Br J Nutr 1998;80:343-52.

48. Kleessen B, Sykura B, Zunft H-J, Blaut M: Effects of inulin and lactose on fecalmicroflora, microbial activity, and bowel habit in elderly constipated persons. Am J Clin Nutr 1997;65:1397-1402

49. Newcomer AD, Park HS, O'Brien PC, McGill DB: Response of patients with irritable bowel syndrome and lactase deficiency using unfermented acidophilus milk. Am J Clin Nutr 1983;38:257-63.

50. Niedzielin $\mathrm{K}$, Kordecki H, Birkenfeld B: A controlled, double-blind, randomised study on the efficacy of Lactobacillus plantarum $299 \mathrm{v}$ in patients with irritable bowel syndrome. Submitted to the Eur J Gastroenterol Hepatol 2001 (In press)

51 *Nobaek S, Johansson ML, Molin G, Ahrne S, Jeppsson B: Alteration of intestinal microflora is associated with reduction in abdominal bloating and pain in patients with irritable bowel syndrome. Am J Gastroenterol 2000; 95:1231-8.

52. Saavedra JM and Abi-Hanna A: Clinical studies of probiotic agents. In: Probiotics, Other Nutritional Factors, and Intestinal Microflora (eds L. Hanson and R.H. Yolken). Linppincott-Raven publ., Philadelphia. Nestlé Nutrition Workshop Series 1999;42:47-61.

53. Pathmakanthan S, Meance S, Edwards CA: Probiotics: A revies of human studies to date and methodological approaches. Microb Ecol Health Dis 2000;suppl 2:10-30

54.*Isolauri E, Juntunen M, Rautanen T, Sillanaukee P, Koivula T. A: Human Lactobacillus strain (Lactobacillus casei sp strain $\mathrm{GG}$ ) promotes recovery from acute diarrhea in children. Pediatrics 1991:88:90-7.

55.*Kaila M, Isolauri E, Soppi E, Virtanen E, Laine S, Arvilommi H: Enhancement of the circulating antibody secreting cell response in human diarrhea by a human Lactobacillus strain. Pediatr Res 1992;32:141-4

56. ${ }^{*}$ Shornikova AV, Casas IA, Isolauri E, Mykkanen H, Vesikari T: Lactobacillus reuteri as a therapeutic agent in acute diarrhea in young children J Pediatr Gastroenterol Nutr 1997;24:399-404.

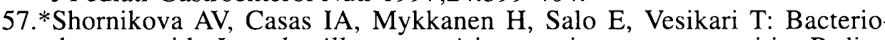
therapy with Lactobacillus reuteri in rotavirus gastroenteritis. Pediatr Infect Dis J 1997;16:1103-7.

58. *olombel JF, Cortot A, Neut C, Romond C: Yoghurt with Bifidobacterium longum reduces erythromycin-induced gastrointestinal effects. Lancet $1987 ; 2: 43$

59.*Orrhage K, Sjostedt S, Nord CE: Effect of supplements with lactic acid bacteria and oligofructose on the intestinal microflora during administration of cefpodoxime proxetil. J Antimicrob Chemother 2000;46:603-12.

60. Siitonen S, Vapaatalo H, Salminen S, Gordin A, Saxelin M, Wikberg R, et al: Effect of Lactobacillus GG yoghurt in prevention of antibiotic associated diarrhoea. Ann Med 1990;22:57-9.

61*Arvola T, Laiho K, Torkkeli S, Mykkanen H, Salminen S, Maunula L, et al. Prophylactic Lactobacillus GG reduces antibiotic-associated diarrhea in children with respiratory infections: a randomized study. Pediatrics 1999; 104:64

62.*McFarland LV, Surawicz CM, Greenberg RN, Fekety R, Elmer GW, Moye KA, et al: A randomized placebo-controlled trial of Saccharomyces boulardii in combination with standard antibiotics for Clostridium difficile disease. Jama 1994;271:1913-8

63. Gorbach SL, Chang TW, Goldin B: Successful treatment of relapsing 
Clostridium difficile colitis with Lactobacillus GG. Lancet 1987;2:1519. 64. Biller JA, Katz AJ, Flores AF, Buie TM, Gorbach SL: Treatment of recurrent Clostridium difficile colitis with Lactobacillus GG. J Pediatr Gastroent Nutr 1995;21:224-6.

65.*Bennet RG, Gorbach SL, Goldin BR, Chang T-W, Laughon BE, Greenough IWB, et al: Treatment of relapsing Clostridium difficile diarrhea with Lactobacillus GG. Nutrition Today 1996;31(6, Suppl 1):35S-38S.

66. Johansson ML, Molin G, Jeppsson B, Nobaek S, Ahrné S, Bengmark S: Administration of different Lactobacillus strains in fermented oatmeal soup: in vitro colonization of human intestinal mucosa and effect on the indigenous flora. Appl Environ Microbiol 1993;59:15-20.

67. Alander M, Satokari R, Korpela R, Saxelin M, Vilpponen-Salmela T, Mattila-Sandholm T, von Wright A: Persistence of colonization of human colonic mucosa by a probiotic strain, Lactobacillus rhamnosus $\mathrm{GG}$, after oral consumption. Appl Enivon Microbiol 1999;65:351-4.

68. Ahrné S, Nobaek S, Jeppsson B, Adlerberth I, Wold A.E, Molin G: The normal Lactobacillus flora of healthy human oral and rectal mucosa. JAppl Microbiol 1998;85:88-94

69. Vesa T, Pochart P, Marteau P: Pharmacokinetics of Lactobacillus plantarum NCIMB 8826, Lactobacillus fermentum KLD, and Lactococcus lactis MG 1363 in the human gastrointestinal tract. Aliment Pharmacol Ther 2000;14:823-8

70. Rambaud JC, Bouhnik Y, Marteau P, Pochart P: Manipulation of the human gut microflora. Proc Nutr Soc 1993;52;357-66.

71. Kaila M, Isolauri E, Saxelin M, Arvilommi H, Vesikari T: Viable versus inactivated Lactobacillus strain GG in acute rotavirus diarrhoea. Arch Dis Child 1995;72:51-3.

72. Ciancio MJ, Chang EB: Epithelial secretory response to inflammation. Ann N Y Acad Sci 1992;664:210-21.

73. Rocha MFG, Soares AM, Flores CA, Steiner T.S, Lyerly DM, Guerrant RL, Ribeiro RA, Lima AAM: Intestinal secretory factor released by macrophages stimulated with Clostridium difficile toxin A: role of interleukin-1b. Infect Immun 1998;66:4910-6.

74. Johansson E, Lönnrot I, Lange S et al: Molecular cloning and expression of a pituitary gland protein modulating intestinal fluid secretion. J Biol Chem 1995;270:20615-20.

75. Karlsson S, Lindberg A, Norin E, Burman LG, Åkerlund T: Toxins, butyric acid, and other short chain fatty acidsare coordinately expressed and downregulated by cysteine in Clostridium difficile. Infect Immun 2000:68:5881-8.

76. Michetti P, Dorta G, Wisel PH, Brassart D, Verdu E, Herranz M, Felley C, Porta N, Rouvet M, Blum AL, Corthésy-Theulaz I: Effect of whey-based culture supernatant of Lactobacillus acidophilus (johnsonii) Lal on Helicobacter pylori Infection in humans Digestion 1999;60:203-209.

77. Canducci F et al: A lyophilized and inactivated culture of Lactobacillus acidophilus increases Helicobacter pylori eradication rates. Aliment Pharmacol Ther 2000;14:1625-9.

78. Gionchetti P, Rizzello F, Venturi A, Brigidi, P, Matteuzzi D, Bazzocchi G, Poggioli G, Miglioli M, Campieri M: Oral bacteriotherapy as maintenance treatment in patients with chronic pouchitis: A double-blind, placebocontrolled trial. Gastroenterology 2000;119:305-9.

79. Xavier RJ, Podolsky DK: How to get along - friendly microbes in a hostile world. Science 2000;289;1483-4.

80. Campieri M, Gionchetti P: Probiotics in inflammatory bowel disease. New insight to pathogenesis or a possible therapeutic alternative? Gastroenterology 1999;116:1246-60.
81. Burns AJ, Rowland JR: Anti-carcinogenicity of probiotics and prebiotics. Curr Issues Intestinal Microbiol 2000;1:13-24.

82. Hirayama K, Rafter J: The role of probiotic bacteria in cancer prevention. Microbes Infect 2000;2:681-6.

83. Hosoda M, Hashimoto H, He D, Morita H, Hosono A: Effect of administration of milk fermented with Lactobacillus acidophilus LA-2 on fecal mutagenicity and microflora in the human intestine. J Dairy Sci 1996;79: $745-9$.

84. Aso Y, Akazan H: Prophylactic effect of a Lactobacillus casei preparation on the recurrence of superficial bladder cancer. Urol Int 1992;49:125-9.

85. Aso Y, Akaza H, Kotake T, Tsukamoto T, Imai K, Naito S: Preventive effect of a Lactobacillus casei preparation on the recurrence of superficial bladder cancer in a double-blind trial. The BLP Study Group. Eur Urol 1995; 27 : 104-9.

86. Henriksson R, Franzén L, Sandström K, Nordin A, Arevärn M, Grahn E: Effects of active addition of bacterial cultures in fermented milk to patients with chronic bowel discomfort following irradiation. Support Care Cancer 1995;3:81-3.

87. Salminen E, Elomaa, I, Minkkinen J, Vapaatalo H, Salminen S: Preservation of intestinal integrity during radiotherapy using live Lactobacillus acidophilus cultures. Clin Radiol 1988;39:435-7.

88. Otha A, Ohtsuki M, Baba S, Takizawa T, Adachi T, Kimura S: Effect of fructooligosaccharides on the absorption of iron, calcium, and magnesium in iron deficient anemic rats. J Nutr Sci Vitaminology 1995;41:281-91.

89. Scholz-Ahrens K, Van Loo J, Schrezenmeyer J: Oligofructose stimuliert die Femurmineralisation in Abhängigkeit von der Calciumzufuhr bei der ovariektomisierten Ratte (The increase in bone mineralization in the ovarectomized rat by oligofructose also depends on Ca supplementation). Zeitschrift für Ernährungswissenschaft 1998;37:123-4.

90* Coudray C, Bellanger J, Castiglia-Delavaud C, Remesy C, Vermorel M, Rayssignuier Y: Effect of soluble or partly soluble dietary fibres supplementation on absorption and balance of calcium, magnesium, iron and zinc in healthy young men. Eur J Clin Nutr 1997;51:375-80.

91.*van den Heuvel EG, Schaafsma G, Muys T, van Dokkum W: Nondigestible oligosaccharides do not interfere with calcium and nonheme-iron absorption in young, healthy men. Am J Clin Nutr 1998;67:445-51.

92.*van den Heuvel EGHM, Muys T, Van Dokkum W, Schaafsma G: Oligofructose stimulates calcium absorption in adolescents. Am J Clin Nutr 1999;69:544-8.

93. Marteau P: Safety aspects of probiotic products. Scand J Nutr 2001;45:22-4.

94. Saxelin M, Chuang NH, Chassy B, Rautelin H, Mäkelä PH, Salminen S, Gorbach SL: Lactobacilli and bacteriemia in Southern Finland, 1989-1992. Clin Infect Dis 1996;22:564-6.

95. Antony, Suresh J: Lactobacillemia: An emerging cause of infection in both the immunocompromised and the immunocompetent host. J Natl Med Assoc 2000;92:83-6.

96. Fruchart C, Salah A, Gray C, Martin E, Stamatoulla A, Bonmarchand G, Lemeland IF, Tilly H: Lactobacillus species as emerging pathogens in neutropenic patients. Eur Clin Microbiol Infect Dis 1997;16:681-4.

97. Anon: Safety evaluation of fructans.Nordic Council of Ministers, Copenhagen 2000; TemaNord 2000:523;pp115.

The article continues with Tables 1-4. 
Table 1.Studies on lactose intolerance, blood lipids, hypertension and irritable bowel syndrome, columns 1-6 (cont).

\begin{tabular}{|c|c|c|c|c|c|}
\hline 1. Ref. & 2. Main hypothesis & 3. Intervention method & 4. Study design & $\begin{array}{l}\text { 5. Recruitment/ } \\
\text { Inclusion criteria }\end{array}$ & $\begin{array}{l}\text { 6. Exclusion } \\
\text { criteria }\end{array}$ \\
\hline Mustapha et al (6) & $\begin{array}{l}\text { Improvement of lactose } \\
\text { digestion with unfer- } \\
\text { mented acidophilus milk }\end{array}$ & Acidophilus test milks & RCT, double-blind & 11 maldigesting subjects & \\
\hline Montes et al (7) & $\begin{array}{l}\text { Reduction of symptoms } \\
\text { and reduced } \mathrm{H}_{2} \text { excretion } \\
\text { with a yoghurt culture }\end{array}$ & $\begin{array}{l}250 \mathrm{ml} \text { milk with } \\
\text { L. acidophilus or yoghurt }\end{array}$ & CT & $\begin{array}{l}20 \text { children with low } \\
\text { lactase activity }\end{array}$ & \\
\hline Lin et al (8) & $\begin{array}{l}\text { L. acidophilus reduces } \\
\text { breath hydrogen values }\end{array}$ & $\begin{array}{l}\text { 1. } 400 \mathrm{ml} \mathrm{milk} \\
\text { 2. } 400 \mathrm{ml} \text { acidophilus milk } \\
\text { 3. } 400 \mathrm{ml} \text { yoghurt }\end{array}$ & CT & & \\
\hline Vesa et al (9) & $\begin{array}{l}\text { Different digestibility and } \\
\text { tolerance of lactose from } \\
\text { products with different } \\
\text { lactase contents and } \\
\text { bacterial cultures }\end{array}$ & $\begin{array}{l}10 \mathrm{~g} \text { of lactuloses and } 18 \mathrm{~g} \\
\text { of lactose in } \\
\text { 1. Youghurt } \\
\text { 2. Milk with L. acidophilus } \\
\text { and bifidobact. } \\
\text { 3. Milk with L. bulgaricus }\end{array}$ & $\begin{array}{l}\text { Metabolic ward study } \\
\text { RCT and cross-over }\end{array}$ & $\begin{array}{l}\text { Lactase-deficient healthy } \\
\text { subjects }\end{array}$ & \\
\hline Shermakk et al (10) & $\begin{array}{l}\text { Yoghurt improves lactose } \\
\text { malabsorption and } \\
\text { symptoms in children }\end{array}$ & $\begin{array}{ll}1 & 12 \mathrm{~g} \text { lactose in milk } \\
2 & 12 \mathrm{~g} \text { lactose in yoghurt }\end{array}$ & CT & 14 children & \\
\hline $\operatorname{Alm}(11)$ & $\begin{array}{l}\text { Acidophilus or yoghurt do } \\
\text { not give symptoms in } \\
\text { lactose intolerant subjects }\end{array}$ & $\begin{array}{l}500 \mathrm{ml} \text { yoghurt } \\
500 \mathrm{ml} \text { acidophilus } \\
500 \mathrm{ml} \text { milk }\end{array}$ & Trial & $\begin{array}{l}\text { Lactose intolerant } \\
\text { subjects controls }\end{array}$ & \\
\hline Teuri et al (12) & $\begin{array}{l}\text { Fructo-oligosaccharides } \\
\text { cause symptoms in lactose } \\
\text { maldigesters }\end{array}$ & $\begin{array}{l}\text { 1. } 50 \mathrm{~g} \text { lactose } \\
\text { 2. } 50 \mathrm{~g} \text { sucrose } \\
\text { 3. } 25 \text { g lactose } \\
\text { 4. } 25 \text { g fructooligo- } \\
\text { saccharides }\end{array}$ & $\mathrm{CT}$ & & \\
\hline De Roos et al (14) & $\begin{array}{l}\text { L. acidophilus strain L-1 } \\
\text { lowers serum cholesterol }\end{array}$ & $\begin{array}{l}500 \mathrm{ml} \text { of yoghurt } \\
1 . \text { with and } \\
2 \text { without L. acidophilus }\end{array}$ & $\begin{array}{l}\mathrm{RCT} \\
\text { Parallel trial }\end{array}$ & $\begin{array}{l}\text { Healthy free-living } \\
\text { subjects }\end{array}$ & $\begin{array}{l}\text { Serum cholesterol } \\
\text { more than } \\
7.8 \mathrm{mmol} / \mathrm{l}\end{array}$ \\
\hline Massey (15) & $\begin{array}{l}\text { Milk and yoghurt reduces } \\
\text { lipoproteins }\end{array}$ & $\begin{array}{l}\text { 1. a) } 1500 \mathrm{ml} \text { milk } \\
\text { b) no milk } \\
\text { c) } 1250 \mathrm{ml} \text { nonfat milk } \\
\text { 2. a) } 480 \mathrm{ml} \text { low fat } \\
\text { yoghurt } \\
\text { 3. b) no yoghurt }\end{array}$ & CT & $\begin{array}{l}\text { 1. } 32 \text { healthy men } \\
\text { 2. } 30 \text { healthy women }\end{array}$ & \\
\hline Lin et al (16) & $\begin{array}{l}\text { L. acidophilus and } \\
\text { bulgaricus lower serum } \\
\text { cholesterol }\end{array}$ & $\begin{array}{l}\text { 1. Tablets containing about } \\
\times 10^{6} \text { viable bacteria of } \\
\text { Lactobacillus } \\
\text { 2. placebo (dead bacteria) }\end{array}$ & $\begin{array}{l}\text { 1.In vitro study } \\
\text { 2.RCT, cross-over }\end{array}$ & \begin{tabular}{|ll}
1 & Normal subjects \\
2 & Medium cholesterol \\
& population \\
3 & High cholesterol \\
& population \\
4 & $\begin{array}{l}\text { Regular exercise } \\
\text { population }\end{array}$ \\
\end{tabular} & - \\
\hline Schaafsma et al (17) & $\begin{array}{l}\text { L. acidophilus reduces } \\
\text { serum cholesterol }\end{array}$ & $\begin{array}{l}\text { 1. } 125 \mathrm{ml} \text { of a product with } \\
\text { L. acidophilus } \\
\text { 2. } 125 \mathrm{ml} \text { of traditional } \\
\text { yoghurt }\end{array}$ & RCT, cross-over & Healthy subjects & \\
\hline Anderson et al (18) & $\begin{array}{l}\text { Fermented milk } \\
\text { containing L. acidophilus } \\
\text { reduces serum } \\
\text { cholesterol in } \\
\text { hypercholesterolemic } \\
\text { subjects }\end{array}$ & & RCT & & \\
\hline Bukowska et al (20) & $\begin{array}{l}\text { L. plantarum } 299 \mathrm{v} \\
\text { lowers serum cholesterol }\end{array}$ & $\begin{array}{l}\text { 1. } 200 \mathrm{ml} \text { Pro Viva } \\
\text { 1. } 200 \mathrm{ml} \text { rose-hip drink }\end{array}$ & RT, Parallel design & Healthy subjects & $\begin{array}{l}\text { Cardiovascular } \\
\text { disease,diabetes or } \\
\text { hypertention }\end{array}$ \\
\hline $\begin{array}{l}\text { Agerholm-Larsen } \\
\text { et al }(21)\end{array}$ & $\begin{array}{l}\text { GAIO (Enterococcus } \\
\text { faecium and } \\
\text { Streptococcus } \\
\text { thermophilus) lowers } \\
\text { serum cholesterol }\end{array}$ & $\begin{array}{l}450 \mathrm{ml} \\
\text { 1. yoghurt (s.t. and e.f.) } \\
\text { 2. placebo yoghurt } \\
\text { 3. yoghurt, } 2 \text { other strains } \\
\text { 4. GAIO }\end{array}$ & $\begin{array}{l}\mathrm{RCT} \\
\text { Parallel test }\end{array}$ & $\begin{array}{l}\text { Healthy overweight } \\
\text { women }\end{array}$ & \\
\hline Agerbaek et al (22) & $\begin{array}{l}\text { GAIO lowers serum } \\
\text { cholesterol }\end{array}$ & $\begin{array}{l}200 \mathrm{ml} \\
\text { 1. GAIO } \\
\text { 2. placebo GAIO }\end{array}$ & $\mathrm{RCT}$ & Healthy weight stable & \\
\hline Rickelsen et al (23) & $\begin{array}{l}\text { GAIO lowers serum } \\
\text { cholesterol after } 6 \\
\text { months }\end{array}$ & $\begin{array}{l}200 \mathrm{ml} \text { of } \\
\text { 1. GAIO } \\
\text { 2. Placebo GAIO }\end{array}$ & RCT & Healthy subjects & \\
\hline Bertolami et al (24) & $\begin{array}{l}\text { GAIO lowers serum } \\
\text { cholesterol }\end{array}$ & $\begin{array}{l}\text { 1. } 200 \mathrm{ml} \mathrm{GAIO} \mathrm{or} \\
\text { 2. } 200 \mathrm{ml} \text { placebo GAIO }\end{array}$ & RTC & Healthy subjects & \\
\hline Andersson et al (25) & $\begin{array}{l}\text { Reduced cholesterol } \\
\text { absorption and increased } \\
\text { cholesterol or bile acid } \\
\text { excretion with Verum } \\
\text { Hälsofil }\end{array}$ & $\begin{array}{l}\text { 1. } 1000 \mathrm{ml} \text { low-fat milk } \\
\text { 2. } 1000 \mathrm{ml} \text { Verum Hälsofil } \\
\text { 3. } 1000 \mathrm{ml} \text { of lemonade }\end{array}$ & $\begin{array}{l}\text { RCT } \\
\text { Constant diet }\end{array}$ & Ileostomy subjects & $\begin{array}{l}\text { High bile acid } \\
\text { excretion }\end{array}$ \\
\hline Yamashita et al (29) & $\begin{array}{l}\text { Fructooligosaccarides } \\
\text { reduces serum } \\
\text { cholesterol }\end{array}$ & $\begin{array}{l}\text { 1. } 8 \text { g per day of } \\
\text { fructooligosaccarides } \\
\text { 2. } 5 \text { g per day of } \\
\text { sucrose }\end{array}$ & RCT no cross-over & Subjects with diabetes & 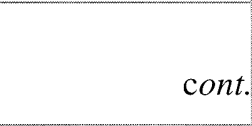 \\
\hline
\end{tabular}


Table 1.Studies on lactose intolerance, blood lipids, hypertension and irritable bowel syndrome, columns 1-6 (cont).

\begin{tabular}{|c|c|c|c|c|c|}
\hline Brighenti et al (30) & $\begin{array}{l}\text { Inulin reduces serum } \\
\text { cholesterol }\end{array}$ & $\begin{array}{l}\text { 1. } \text { Placebo } \\
\text { 2. Placebo + Inulin } \\
\text { 3. Habitual diet }\end{array}$ & RCT & Healthy male volonteers & \\
\hline Canzi et al (31) & $\begin{array}{l}\text { Inulin lowers serum } \\
\text { cholesterol }\end{array}$ & $\begin{array}{l}\text { 1. } 50 \mathrm{~g} \text { of cereals } \\
\text { 2. } 50 \mathrm{~g} \text { of cereals } \\
\text { 3. } 9 \mathrm{~g} \text { inulin }\end{array}$ & $\mathrm{CT}$ & Healthy subjects & \\
\hline Davidson et al (32) & $\begin{array}{l}\text { Inulin reduces serum } \\
\text { cholesterol }\end{array}$ & $\begin{array}{ll}\text { 1. } & 18 \mathrm{~g} \text { inulin } / \mathrm{d} \\
2 & \text { No inulin } \\
\end{array}$ & RCT, cross-over & $\begin{array}{l}\text { Men and women with } \\
\text { hypercholesterolemia }\end{array}$ & \\
\hline Pedersen et al (33) & $\begin{array}{l}\text { Inulin lowers serum } \\
\text { cholesterol }\end{array}$ & $\begin{array}{l}\text { 1. } 14 \mathrm{~g} \text { of inulin in } 40 \mathrm{~g} \\
\text { margarine } \\
\text { 2. } 40 \mathrm{~g} \text { margarine }\end{array}$ & RCT & Normolipidemic women & \\
\hline Alles et al (34) & $\begin{array}{l}\text { Fructooligosaccarides } \\
\text { reduces serum cholesterol }\end{array}$ & $\begin{array}{ll}\text { 1. } & 15 \mathrm{~g} \text { fructo- } \\
\text { oligosacharides } \\
\text { 2. } \\
4 \mathrm{~g} \text { placebo }\end{array}$ & CRT & Type 2 diabetes & \\
\hline van Doccum et al (35) & $\begin{array}{l}\text { Oligosaccarides reduces } \\
\text { serum lipids }\end{array}$ & $\begin{array}{ll}\text { 1. } & \text { Inulin } \\
\text { 2. } & \text { Fructo-oligosaccarides } \\
\text { 3. } & \text { Galacto-oligosaccarides } \\
\text { 4. } & \text { Control }\end{array}$ & $\begin{array}{l}\mathrm{R} \text { double-blind,diet } \\
\text { controlled }\end{array}$ & Healthy men & \\
\hline Luo et al (36) & $\begin{array}{l}\text { Fructooligosaccharides } \\
\text { (FOS) influences glucose } \\
\text { and lipid metabolism }\end{array}$ & $\begin{array}{ll}\text { 1. } & 20 \text { FOS } \\
\text { 2. } & \text { Placebo }\end{array}$ & CRT & Type 2 diabetes & \\
\hline Jackson et al (37) & $\begin{array}{l}\text { Inulin reduces lipids and } \\
\text { glucose }\end{array}$ & $\begin{array}{l}\text { 1. } 10 \mathrm{~g} \text { inulin } \\
\text { 2. Placebo }\end{array}$ & CT & Healthy men and women & \\
\hline Ellegård et al (38) & $\begin{array}{l}\text { Inulin lowers serum } \\
\text { cholesterol and influences } \\
\text { mineral absorption }\end{array}$ & $\begin{array}{l}\text { 1. } 17 \mathrm{~g} \text { inulin } \\
\text { 2. } 17 \mathrm{~g} \text { oligofructos } \\
\text { 3. } 7 \mathrm{~g} \text { sacrose ( placebo ) }\end{array}$ & $\begin{array}{l}\text { RCT } \\
\text { Constant diet }\end{array}$ & Ileostomy subjects & \\
\hline Hata et al (39) & $\begin{array}{l}\text { Sour milk reduces blood } \\
\text { pressure in hypertensive } \\
\text { subjects }\end{array}$ & $\begin{array}{l}\text { 1. } 95 \mathrm{ml} \mathrm{Calpis,} \mathrm{sour} \mathrm{milk} \\
\text { 2. } 95 \mathrm{ml} \text { placebo-milk }\end{array}$ & RCT, parallel design & Hypertensive subjects & \\
\hline Kawase et al (40) & $\begin{array}{l}\text { Fermented milk reduces } \\
\text { serum lipids and blood } \\
\text { pressure }\end{array}$ & $\begin{array}{l}\text { 1. } 200 \mathrm{ml} \text { fermented milk } \\
\text { 2. Placebo }\end{array}$ & $\mathrm{CT}$ & & \\
\hline Ling et al (41) & $\begin{array}{l}\text { Colonization of faeces by } \\
\text { Lactobacillus } G G \text { and } \\
\text { effects on bowel function }\end{array}$ & $\begin{array}{l}\text { 1. } 200 \mathrm{ml} \text { placebo } \\
\text { 2. } 200 \mathrm{ml} \text { Lactobacillus } \\
\text { 3. } 200 \text { placebo }\end{array}$ & $\mathrm{CT}$ & & \\
\hline Alm (43) & $\begin{array}{l}\text { Acidophilus milk } \\
\text { alleviates constipation }\end{array}$ & & $\begin{array}{l}\text { Cross-sectional } \\
\text { or cross-over study }\end{array}$ & $\begin{array}{l}\text { Constipated subjects } \\
\text { from a geriatric ward }\end{array}$ & \\
\hline Newcomer et al (49) & $\begin{array}{l}\text { Symptoms would be } \\
\text { reduced in IBS and } \\
\text { lactase-deficient subjects } \\
\text { (using acidophilus milk) }\end{array}$ & $\begin{array}{l}\text { 1. } 240 \mathrm{ml} \times 3 \text { of ordinary } \\
\text { milk } \\
\text { 2. } 240 \mathrm{ml} \times 3 \text { of } \\
\text { acidophilus milk }\end{array}$ & Double-blind RCT & $\begin{array}{ll}\text { 1. } & \text { IBS ( 61) } \\
\text { 2. } & \text { Lactase-deficient } \\
& (18) \\
\text { 3. } & \text { Healthy sbjects (10) }\end{array}$ & - \\
\hline Niedzielin et al (50) & Reduction of symptoms & $\begin{array}{ll}\text { 1. } & \text { Pro Viva } \\
\text { 2. } & \text { Placebo } \\
\end{array}$ & RT, parallel test & IBS & $\begin{array}{l}\text { Inflammatory bowel } \\
\text { disease }\end{array}$ \\
\hline Nobaek et al. (51) & $\begin{array}{l}\text { L. plantarum DSM } 9843 \\
\text { reduces abdominal } \\
\text { bloating and pain }\end{array}$ & $\begin{array}{l}\text { 3. } 400 \mathrm{ml} \text { of a rose-hip } \\
\text { drink } \\
\text { 4. } 400 \mathrm{ml} \text { of rose-hip } \\
\text { drink containing } \\
\text { L. plantarum, } 5 \times 10^{7} \\
\text { CFU and } 0.009 \mathrm{~g} / \mathrm{ml} \text { of } \\
\text { oat flour }\end{array}$ & RCT & $\begin{array}{l}\text { Patients with irritable } \\
\text { bowel syndrome (IBS ) }\end{array}$ & $\begin{array}{l}\text { Malabsorption or } \\
\text { patients less than } 18 \\
\text { years old. }\end{array}$ \\
\hline
\end{tabular}


Table 1.Studies on lactose intolerance, blood lipids, hypertension and irritable bowel syndrome, columns 7-10 (cont).

\begin{tabular}{|c|c|c|c|c|c|c|}
\hline \multirow[t]{2}{*}{ Ref. } & \multirow[t]{2}{*}{ 7. Matching of groups } & \multirow[t]{2}{*}{ 8. Treatment time } & \multirow{2}{*}{$\begin{array}{l}\text { 9. Follow up after treatment } \\
\text { (if any, e.g. persistence of } \\
\text { probiotic organism in faeces, } \\
\text { recurrence of symptoms) }\end{array}$} & \multicolumn{3}{|c|}{ 10. Number of subjects/patients } \\
\hline & & & & $\begin{array}{l}\text { Number } \\
\text { starting }\end{array}$ & $\begin{array}{l}\text { Number ending } \\
\text { experimental } \\
\text { period }\end{array}$ & $\begin{array}{l}\text { Number } \\
\text { followed up } \\
\text { (if any) }\end{array}$ \\
\hline 6 & Cross over & hours & & 11 & & \\
\hline 7 & No cross-over & hours & & 20 children & & \\
\hline 8 & Same subjects & & & & & \\
\hline 9 & Own controls & 8 hours $\times 4$ & 3-15 days wash-out & 15 & & 14 \\
\hline 10 & No cross-over & 8 hours & & 14 children & & \\
\hline 11 & Same subjects & hours & & 8 & & \\
\hline 12 & Cross-over & 8 hours & & 40 & & \\
\hline 14 & $\begin{array}{l}\text { Stratification for sex, age, } \\
\text { s-cholesterol }\end{array}$ & 6 weeks & & 85 & & $78(2 \times 39)$ \\
\hline 15 & Cross-over & 3-4 weeks & & $32+30$ & & \\
\hline 16 & Cross-over study & $2 \times 6$ weeks & & $\begin{array}{l}\text { Test/control } \\
157 / 177 \\
\end{array}$ & & \\
\hline 17 & Cross-over & $2 \times 3$ weeks, wash out & & 30 & & 30 \\
\hline 18 & Cross-over & $\begin{array}{l}4 \text { weeks }+2 \text { weeks } \\
+4 \text { weeks }\end{array}$ & & & & \\
\hline 20 & No cross- over & 6 weeks & & 30 & & 30 \\
\hline 21 & $\begin{array}{l}\text { Matched for sex, age BMI, HDL, } \\
\text { LDL }\end{array}$ & 8 weeks & & 73 & & 70 \\
\hline 22 & $\begin{array}{l}\text { Treatment group } 0.21 \mathrm{mmol} \\
\text { higher }\end{array}$ & 6 weeks & & 58 & & $\begin{array}{l}29 \text { GAIO } \\
28 \text { placebo }\end{array}$ \\
\hline 23 & Randomised, good comparison & 6 months & & 90 & & 87 \\
\hline 24 & Cross-over & $2 \times 8$ weeks & & 32 & & 32 \\
\hline 25 & Same subjects, cross-over & $3 \times 3$ days & & 9 & & 9 \\
\hline 29 & 18 treated 10 controls & 2 weeks & & $18 / 10$ & & $18 / 10$ \\
\hline 30 & Cross-over & $3 \times 4$ weeks & & 12 & & \\
\hline 31 & Same subjects & $2 \times 4$ weeks & & 12 & & 12 \\
\hline 32 & Cross-over & $2 \times 3$ weeks, wash out & & 21 & & 21 \\
\hline 33 & Cross-over & $2 \times 4$ weeks & & 72 & & 64 \\
\hline 34 & Cross-over & 20 days +20 days & & 20 & & \\
\hline 35 & Cross-over & $4 \times 3$ weeks & & 12 & & \\
\hline 36 & Cross-over & $2 \times 4$ weeks & & 10 & & \\
\hline 37 & Parallel study & 8 weeks & & 54 & & \\
\hline 38 & Same subjects, cross-over & $3 \times 3$ days & & 10 & & 10 \\
\hline 39 & Randomisation & 8 weeks & & 30 & & \\
\hline 40 & Cross-over & 8 weeks & & & & \\
\hline 41 & Same subjects & $\begin{array}{l}\text { Three two weeks periods } \\
\text { (baseline, test, baseline ) }\end{array}$ & & 12 & & 6 \\
\hline 43 & Same subjects & 36-105 days & & 50 & & \\
\hline 49 & Own controls & $2+2$ weeks & 2 weeks wash out & 89 & & 61 \\
\hline 50 & Rand for age, gender & 4 weeks & & $20+20$ & & $20+20$ \\
\hline 51 & Randomized into two groups & 4 weeks & & $30+30$ & & $25+27$ \\
\hline
\end{tabular}


Table 1.Studies on lactose intolerance, blood lipids, hypertension and irritable bowel syndrome, columns 11-14 (cont).

\begin{tabular}{|c|c|c|c|c|c|c|c|c|c|}
\hline \multirow{3}{*}{ Ref. } & \multicolumn{6}{|c|}{ 11. Results } & \multirow{3}{*}{$\begin{array}{l}12 . \\
\text { a. Side effects } \\
\text { b. Compliance } \\
\text { measure }\end{array}$} & \multirow{3}{*}{$\begin{array}{l}\text { 13. Evaluation } \\
\text { of quality }\end{array}$} & \multirow{3}{*}{$\begin{array}{l}\text { 14. Concluding remarks } \\
\text { - strength of evidence }\end{array}$} \\
\hline & \multicolumn{2}{|c|}{ Main outcome } & \multicolumn{2}{|c|}{ Other effects } & \multicolumn{2}{|c|}{ Drop-outs } & & & \\
\hline & Treatment & Control & Treatment & Control & $\begin{array}{c}\text { Treat } \\
\text {-ment }\end{array}$ & $\begin{array}{l}\text { Con- } \\
\text { trol }\end{array}$ & & & \\
\hline 6 & $\begin{array}{l}\text { Reduced total } \mathrm{H}_{2} \\
\text { production }\end{array}$ & & & & & & & + & $\begin{array}{l}\text { Acidophilus milk } \\
\text { improves lactose } \\
\text { tolerance and digestion }\end{array}$ \\
\hline 7 & $\begin{array}{l}\text { Reduction of } \\
\text { symptoms and } \mathrm{H}_{2} \\
\text { with a yoghurt } \\
\text { culture }\end{array}$ & & & & & & & + & $\begin{array}{l}\text { Less symptoms with } \\
\text { yoghırt }\end{array}$ \\
\hline 8 & $\begin{array}{l}\text { Yoghurt delayed } \\
\text { breath } \mathrm{H}_{2} \text { peak and } \\
\text { gave lower values } \\
\text { than in the control }\end{array}$ & & & & & & & + & $\begin{array}{l}\text { Only vie strain of LA-1 } \\
\text { significantly decreased } \\
\text { breath hydrogen values }\end{array}$ \\
\hline 9 & $\begin{array}{l}\text { No difference in } \\
\text { breath } \mathrm{H}_{2} \text { con- } \\
\text { centrations after } \\
\text { the three test } \\
\text { products, no } \\
\text { diffenence in } \\
\text { symptom scores }\end{array}$ & $\begin{array}{l}\text { Lactulose and } \\
\text { lactose gave } \\
\text { higher scores }\end{array}$ & & & 1 & & $\begin{array}{l}12 / 14 \text { had } \\
\text { symptoms }\end{array}$ & ++ & $\begin{array}{l}\text { Despite the difference in } \\
\text { lactase and bacterial } \\
\text { content, lactose was as } \\
\text { well digested and } \\
\text { tolerated from the three } \\
\text { different fermented dairy } \\
\text { products }\end{array}$ \\
\hline 10 & $\begin{array}{l}\text { Lactose absorbed } \\
\text { better from yog- } \\
\text { hurt than milk }\end{array}$ & & & & & & & + & $\begin{array}{l}\text { Less symptoms with } \\
\text { yoghurt }\end{array}$ \\
\hline 11 & $\begin{array}{l}\text { Milk induced more } \\
\text { symptoms than } \\
\text { yoghurt and } \\
\text { acidophilus in non- } \\
\text { Swedish subjects }\end{array}$ & & & & & & & ++ & $\begin{array}{l}\text { Less amount of lactose } \\
\text { gives less symptoms in } \\
\text { lactose intolerant } \\
\text { subjects }\end{array}$ \\
\hline 12 & $\begin{array}{l}\text { More symptoms } \\
\text { with undigestible } \\
\text { carbohydrates }\end{array}$ & & & & & & & ++ & $\begin{array}{l}\text { More symptoms with } \\
\text { oligo-saccharides in low } \\
\text { lactase activity subjects }\end{array}$ \\
\hline 14 & $\begin{array}{l}\text { S-cholesterol } \\
\text { reduced by } \\
0.02 \mathrm{mml} / \mathrm{l}\end{array}$ & $\begin{array}{l}\text { S-cholesterol } \\
\text { reduced by } \\
0.07 \mathrm{mmol} / 1\end{array}$ & $\begin{array}{l}\text { Unaffected } \\
\text { levels of } \\
\text { LDL, HDL } \\
\text { and triacyl- } \\
\text { glycerol }\end{array}$ & & $\begin{array}{l}6 \text { in } \\
\text { all }\end{array}$ & & $\begin{array}{l}\text { Abdominal } \\
\text { symptoms in } \\
\text { one subject }\end{array}$ & +++ & $\begin{array}{l}\text { Addition of } \\
\text { L. acidophilus does not } \\
\text { lower serum cholesterol }\end{array}$ \\
\hline 15 & $\begin{array}{l}\text { No effects on } \\
\text { serum lipids }\end{array}$ & & & & & & & +++ & $\begin{array}{l}\text { No effects on serum } \\
\text { lipids }\end{array}$ \\
\hline 16 & $\begin{array}{l}\text { No effect on total } \\
\text { cholesterol, HDL } \\
\text { or triglycerides }\end{array}$ & No effect & & & & & $\begin{array}{l}\text { 6-21\% side } \\
\text { effects with } \\
\text { lactobacillus, } \\
7-15 \% \text { side } \\
\text { effects with } \\
\text { placebo }\end{array}$ & +++ & $\begin{array}{l}\text { No effect on serum } \\
\text { lipids. }\end{array}$ \\
\hline 17 & LDL down: $5,4 \%$ & & & & & & & ++ & Small reduction of LDL \\
\hline 18 & $\begin{array}{l}\text { Serum cholesterol } \\
\text { down by } 2.9 \%\end{array}$ & No effect & & & & & & ++ & $\begin{array}{l}\text { Small effect on serum } \\
\text { cholesterol }\end{array}$ \\
\hline 20 & $\begin{array}{l}\text { s-cholesterol } \\
233 \pm 36 \text { reduced to } \\
216 \pm 33(\mathrm{p}<0.05)\end{array}$ & $\begin{array}{l}\text { s-cholesterol } \\
216 \pm 31 \text { reduced } \\
\text { to } 208 \pm 40\end{array}$ & $\begin{array}{l}\text { Fibrogen no } \\
\text { change }\end{array}$ & & & & & ++ & $\begin{array}{l}\text { Small reduction in } \\
\text { relation to the control } \\
\text { group }\end{array}$ \\
\hline 21 & $\begin{array}{l}\text { Cholesterol } \\
\text { decreased by } 8.4 \%\end{array}$ & $\begin{array}{l}\text { No sign } \\
\text { difference }\end{array}$ & $\begin{array}{l}\text { Fibrinogen } \\
\text { increased by } \\
0.7 \mathrm{mmol} / \mathrm{l}\end{array}$ & & 3 & & $\begin{array}{l}\text { Compliance } \\
\text { measured } \\
\text { Constipation in } \\
\text { two }\end{array}$ & +++ & Mass-sign \\
\hline 22 & $\begin{array}{l}\text { Cholesterol } \\
\text { reduction by } \\
0.37 \mathrm{mmol} / 1\end{array}$ & $\begin{array}{l}\text { Cholesterol } \\
\text { reduction } \\
\text { by } 0.02 \mathrm{mmol} / \mathrm{l}\end{array}$ & $\begin{array}{l}\text { Trigly- } \\
\text { cerides no } \\
\text { difference }\end{array}$ & & & & & ++ & $\begin{array}{l}\text { Small reduction in total } \\
\text { serum cholesterol }\end{array}$ \\
\hline 23 & $\begin{array}{l}\text { Cholesterol down } \\
0.32 \text { after } 3 \\
\text { months, after } 6 \\
\text { months no differ- } \\
\text { ence compared to } \\
\text { control group }\end{array}$ & $\begin{array}{l}\text { After } 6 \text { months } \\
\text { the same } \\
\text { reduction as in } \\
\text { test group }\end{array}$ & $\begin{array}{l}\text { Trigly- } \\
\text { cerides and } \\
\text { HDL no } \\
\text { change }\end{array}$ & $\begin{array}{l}\text { Trigly- } \\
\text { cerides and } \\
\text { HDL no } \\
\text { change }\end{array}$ & 3 & & & +++ & $\begin{array}{l}\text { No difference between } \\
\text { groups after } 6 \text { months. } \\
\text { Milk products may have } \\
\text { a hypocholesterolemic } \\
\text { factor }\end{array}$ \\
\hline 24 & $\begin{array}{l}\text { Serum cholesterol } \\
\text { down by } 5.3 \% \\
\text { LDL down } \\
\text { by } 6.15 \%\end{array}$ & HDL up & & & & & Insignificant & +++ & $\begin{array}{l}\text { Small but sign. reduc- } \\
\text { tion of s-cholesterol } \\
\text { A few subjects showed } \\
\text { an increment }\end{array}$ \\
\hline
\end{tabular}


Table 1.Studies on lactose intolerance, blood lipids, hypertension and irritable bowel syndrome, columns 11-14 (cont).

\begin{tabular}{|c|c|c|c|c|c|c|c|c|c|}
\hline 25 & $\begin{array}{l}\text { Lower cholesterol } \\
\text { absorption with } \\
\text { Verum hälsofil }\end{array}$ & & $\begin{array}{l}\text { Highest } \\
\text { endogenous } \\
\text { cholesterol } \\
\text { excretion } \\
\text { with low fat } \\
\text { milk }\end{array}$ & & & & & +++ & $\begin{array}{l}\text { No difference in net } \\
\text { cholesterol excretion- } \\
\text { lower absorption with the } \\
\text { Verum product } \\
\text { (assimilation of chole- } \\
\text { sterol by bacteria ?) A } \\
\text { hypocholesterolemic } \\
\text { factor in milk? }\end{array}$ \\
\hline 29 & $\begin{array}{l}\text { Serum cholesterol } \\
\text { reduced by } \\
17 \mathrm{mg} / \mathrm{dl}\end{array}$ & No change & & & & & & + & Small reduction \\
\hline 30 & $\begin{array}{l}\text { Total cholesterol } \\
\text { down by } 7.9 \%\end{array}$ & Less reduction & $\begin{array}{l}\text { Triglycerid- } \\
\text { es down by } \\
7.8 \%\end{array}$ & & & & & + & $\begin{array}{l}\text { Inulin seem to have a } \\
\text { lipid lowering potential }\end{array}$ \\
\hline 31 & $\begin{array}{l}\text { Total cholesterol } \\
\text { down to } 150 \mathrm{mg} / \mathrm{l}\end{array}$ & $\begin{array}{l}\text { Total cholesterol } \\
\text { down to } \\
158 \mathrm{mg} / \mathrm{dl}\end{array}$ & $\begin{array}{l}\text { TG } 54,4 \pm \\
4.4\end{array}$ & $\begin{array}{l}\text { TG } 74.8 \pm \\
7.4\end{array}$ & & & & ++ & $\begin{array}{l}\text { Small study } \\
\text { TG down }\end{array}$ \\
\hline 32 & $\begin{array}{l}\text { Total-cholesterol } \\
\text { declined by } 1.3 \% \\
\text { and LDL by } 2 . \%\end{array}$ & $\begin{array}{l}\text { Total cholesterol } \\
\text { increased: } 7.4 \% \\
\text { and LDL chole- } \\
\text { sterol by } 12.3 \%\end{array}$ & $\begin{array}{l}\text { Triglycerides } \\
\text { no difference }\end{array}$ & & & & & ++ & $\begin{array}{l}\text { "Reduction" due to an } \\
\text { increase in the control } \\
\text { group }\end{array}$ \\
\hline 33 & $\begin{array}{l}\text { TC, LDL, HDL no } \\
\text { change }\end{array}$ & $\begin{array}{l}\text { TC LDL,HDL } \\
\text { no change }\end{array}$ & $\begin{array}{l}\text { Triglycerides } \\
\text { no change }\end{array}$ & & 6 & & $\begin{array}{l}\text { Flatulence, } \\
\text { cramps }\end{array}$ & +++ & $\begin{array}{l}\text { No effect on serum } \\
\text { cholesterol of inulin }\end{array}$ \\
\hline 34 & $\begin{array}{l}\text { No effect onTC, } \\
\text { LDL-cholesterol } \\
\text { or triglycerides }\end{array}$ & & & & & & & +++ & $\begin{array}{l}\text { Lack of effect not due to } \\
\text { insufficient statistical } \\
\text { power }\end{array}$ \\
\hline 35 & No sign. difference & & & & & & & ++ & Lack of effect \\
\hline 36 & $\begin{array}{l}\text { Total cholesterol } \\
\text { unchanged }\end{array}$ & & $\begin{array}{l}\text { Glucose } \\
\text { metabolism } \\
\text { unchanged }\end{array}$ & & & & & + & $\begin{array}{l}\text { No effect on glucose and } \\
\text { lipid metabolism. }\end{array}$ \\
\hline 37 & $\begin{array}{l}\text { Inulin reduces } \\
\text { triacylglycerol } \\
\text { levels }(\mathrm{p}<0,08)\end{array}$ & & & & & & & ++ & $\begin{array}{l}\text { Trend for a reduction of } \\
\text { plasma TAG }\end{array}$ \\
\hline 38 & $\begin{array}{l}\text { No difference in } \\
\text { cholesterol } \\
\text { absorption }\end{array}$ & & $\begin{array}{l}\text { No differ- } \\
\text { ence in } \\
\text { mineral } \\
\text { absorption } \\
\text { of the small } \\
\text { bowel }\end{array}$ & & & & & ++ & $\begin{array}{l}\text { No change in cholesterol } \\
\text { metabolism induced by } \\
\text { inulin. No change in } \\
\text { small bowel mineral } \\
\text { absorption }\end{array}$ \\
\hline 39 & $\begin{array}{l}\text { Blood pressure } \\
\text { down, syst. } 14.1 \\
\text { mm Hg. Diast. by } \\
6.9 \text { after } 8 \text { wk } \\
\end{array}$ & No sign change & & & & & & ++ & $\begin{array}{l}\text { Blood pressure } \\
\text { down,small group, } \\
\text { parallel study }\end{array}$ \\
\hline 40 & $\begin{array}{l}\text { HDL increased } \\
\text { after } 4 \text { weeks. } \\
\text { Triglycerides } \\
\text { down. Systolic } \\
\text { blood pressure was } \\
\text { reduced }\end{array}$ & & & & & & & ++ & $\begin{array}{l}\text { Changes in serum lipids. } \\
\text { Lower blood pressure }\end{array}$ \\
\hline 41 & $\begin{array}{l}\text { Colonization of } \\
\text { faeces by } \\
\text { lactobacilli. No } \\
\text { changes in fecal } \\
\text { frequency weight } \\
\text { or pH }\end{array}$ & & $\begin{array}{l}\text { Bowel } \\
\text { frequency } \\
\text { increased in } \\
7 \text { of } 10 \text { pati- } \\
\text { ents to } 8 \text { or } \\
\text { more /week }\end{array}$ & & & & & + & $\begin{array}{l}\text { No changes in bowel } \\
\text { frequency }\end{array}$ \\
\hline 43 & $\begin{array}{l}\text { Reduction in the } \\
\text { need for laxatives }\end{array}$ & & $\begin{array}{l}\text { A tendency } \\
\text { toward } \\
\text { increased } \\
\text { defecation } \\
\text { frequency } \\
\end{array}$ & & & & & ++ & $\begin{array}{l}\text { Non-conclusive results } \\
\text { on the effect on bowel } \\
\text { evacuation frequency }\end{array}$ \\
\hline 49 & $\begin{array}{l}\text { No difference } \\
\text { between test } \\
\text { groups and } \\
\text { controls in } \\
\text { diarrhoea, } \\
\text { bloating, number } \\
\text { of stools and } \\
\text { abdominal pains }\end{array}$ & & & & & & & +++ & $\begin{array}{l}\text { No difference in the } \\
\text { degree of tolerance to } \\
\text { the two varieties of milk }\end{array}$ \\
\hline 50 & $\begin{array}{l}\text { Reduction of } \\
\text { abdominal pain } \\
\text { normalisation of } \\
\text { stool frequency }\end{array}$ & & & & & & & ++ & Effect on symtoms \\
\hline 51 & $\begin{array}{l}\text { Reduction in } \\
\text { flatulence in } 44 \% \text {, } \\
\text { reduction in pain } \\
\text { by } 36 \%\end{array}$ & $\begin{array}{l}\text { Reduction in } \\
\text { flatulence by } \\
18 \% \text {,reduction in } \\
\text { pain by } 18 \%\end{array}$ & $\begin{array}{l}\text { No. of days } \\
\text { with normal/ } \\
\text { hard stools } \\
\text { didn't differ } \\
\text { between test } \\
\text { and placebo } \\
\text { group }\end{array}$ & & 5 & 3 & & ++ & $\begin{array}{l}\text { Decrease pain and } \\
\text { flatulence but does not } \\
\text { change the no of days } \\
\text { with hard or normal } \\
\text { stools on the different } \\
\text { regimens between groups }\end{array}$ \\
\hline
\end{tabular}


Table 2.Studies on diarrhoea, columns 1-6 (cont).

\begin{tabular}{|c|c|c|c|c|c|}
\hline 1. Ref. & 2. Main hypothesis & 3. Intervention method & 4. Study design & \begin{tabular}{|l|} 
5. Recruitment// \\
Inclusion criteria
\end{tabular} & $\begin{array}{l}\text { 6. Exclusion } \\
\text { criteria }\end{array}$ \\
\hline Isolauri et al (54) & $\begin{array}{l}\text { Administration of } \\
\text { L. rhamnosus } \mathrm{GG} \\
\text { promotes recovery from } \\
\text { acute diarrhoea }\end{array}$ & 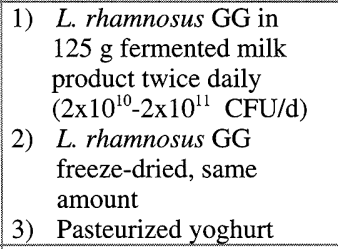 & RCT & \begin{tabular}{|l|}
$4-45$ months \\
Acute diarrhoea of less \\
than 7 days' duration \\
$>3$ watery stools last $24 \mathrm{~h}$ \\
$82 \%$ were positive for \\
rotavirus
\end{tabular} & \\
\hline Kaila et al (55) & $\begin{array}{l}\text { Intake of } L \text { rhamnosus GG } \\
\text { shortens diarrhoea due to } \\
\text { rotavirus infection }\end{array}$ & $\begin{array}{l}\text { 1) } 125 \mathrm{~g} \mathrm{x} 2 \text { per day of } \\
\text { milk product fermented } \\
\text { with } L \text {. rhamnosus GG } \\
\text { 2) } \begin{array}{l}\text { Fermented milk as } \\
\text { above, but pasteurized }\end{array}\end{array}$ & RCT & $\begin{array}{l}\text { Children with acute } \\
\text { gastroenteritis of }<7 \\
\text { days' duration admitted } \\
\text { to hospital during } \\
\text { rotavirus epidemic }\end{array}$ & \\
\hline Shornikova et al (56) & $\begin{array}{l}\text { L. reuteri shortens duration } \\
\text { of acute diarrhoea in } \\
\text { children }\end{array}$ & $\begin{array}{ll}\text { 1) } & 10^{10}-10^{11} \mathrm{CFU} / \mathrm{d} \text { of } \\
& \text { L. reuteri } \mathrm{SD} 2112 \\
\text { 2) } & \text { Placebo (milk powder) }\end{array}$ & $\begin{array}{l}\text { RCT } \\
\text { Double-blind }\end{array}$ & $\begin{array}{l}\text { 6-36 months of age } \\
\text { presenting with acute } \\
\text { diarrhoea ( } 1 \text { or more } \\
\text { watery stool/d) of less } \\
\text { than } 7 \text { days' duration } \\
\text { during rotavirus season } \\
\end{array}$ & $\begin{array}{l}\text { Not previously fed } \\
\text { cow's milk }\end{array}$ \\
\hline Sornikova et al (57) & $\begin{array}{l}\text { L. reuteri shortens duration } \\
\text { of rotavirus-induced acute } \\
\text { diarrhoea in children }\end{array}$ & $\begin{array}{ll}\text { 1) } & 10^{10}-10^{11} \mathrm{CFU} \\
& \text { L. reuteri/d (in capsules } \\
& \text { with lactose) } \\
\text { 2) } & 10^{7} \mathrm{CFU} \text { L. reuteri/d (in } \\
& \text { capsules with lactose) } \\
\text { 3) } & \text { Placebo (capsules with } \\
& \text { lactose only) } \\
\end{array}$ & $\begin{array}{l}\text { RCT } \\
\text { Double-blind }\end{array}$ & $\begin{array}{l}6-36 \text { months of age } \\
\text { presenting with acute } \\
\text { diarrhoea of less than } 7 \\
\text { days' duration and } 3 \text { or } \\
\text { more watery stools per } \\
\text { day during rotavirus } \\
\text { season. }\end{array}$ & $\begin{array}{l}\text { Diarrhoea due to } \\
\text { other causes than } \\
\text { rotavirus and } \\
\text { patients requiring } \\
\text { i.v. fluid treatment. }\end{array}$ \\
\hline Colombel et al (58) & $\begin{array}{l}\text { B. longum-containing } \\
\text { yoghurt prevents } \\
\text { gastrointestinal side effects } \\
\text { of erythromycin treatment }\end{array}$ & $\begin{array}{l}\text { 1) } 3 \text { yoghurt servings per } \\
\text { day with } B \text {. longum } \\
\text { 2) } 3 \text { placebo yoghurt } \\
\text { servings per day } \\
\text { All were given } 1 \text { g erythro- } \\
\text { mycin sulphate for } 3 \text { days } \\
\end{array}$ & $\begin{array}{l}\text { RCT } \\
\text { Double-blind } \\
\text { Cross-over }\end{array}$ & $\begin{array}{l}\text { Healthy men and women } \\
(5+5), \text { mean age } 29 \text { years }\end{array}$ & \\
\hline Orrhage et al (59) & $\begin{array}{l}\text { Milk fermented with } \\
\text { B. longum and } \\
\text { L. acidophilus prevents } \\
\text { C. difficile colonization } \\
\text { and gastrointestinal side } \\
\text { effects cased by antibiotic } \\
\text { treatment }\end{array}$ & $\begin{array}{l}\text { 1) } 250 \mathrm{~g} \text { fermented milk } \\
\text { (L. bulgaricus } 10^{7-8} \\
\text { CFU/ml, S. thermophilus } \\
\left.10^{8-8} \mathrm{CFU} / \mathrm{ml}\right) \text { with } \\
\text { B. longum }\left(1-5 \times 10^{10}\right. \\
\text { CFU/d) and } \\
\text { L. acidophilus }(5-7 \mathrm{x} \\
\left.10^{10} \mathrm{CFU} / \mathrm{d}\right) .15 \mathrm{~g} \\
\text { oligofructose added } \\
\text { 2) Fermented milk with } \\
15 \mathrm{~g} \text { oligofructose } \\
\text { 3) Fermented milk } \\
\text { All: } 100 \mathrm{mg} \text { cefpodoxime proxetil }\end{array}$ & $\begin{array}{l}\text { RCT } \\
\text { Double-blind }\end{array}$ & $\begin{array}{l}\text { Healthy women and men } \\
\text { age } 21-50\end{array}$ & $\begin{array}{l}\text { Antibiotics last } \\
3 \text { months }\end{array}$ \\
\hline Siitonen et al (60) & $\begin{array}{l}\text { L. rhamnosus GG prevents } \\
\text { diarrhoea caused by } \\
\text { antibiotic treatment } \\
\text { (erythromycin) }\end{array}$ & \begin{tabular}{|l|} 
1) $125 \mathrm{ml}$ fermented \\
yoghurt twice daily \\
containing \\
L. rhamnosus $\mathrm{GG}$ \\
2) $125 \mathrm{ml}$ pasteurized \\
yoghurt twice daily \\
All were given erythromycin \\
acistate $400 \mathrm{mg}$ for 7 days \\
\end{tabular} & RCT & $\begin{array}{l}\text { Male healthy volunteers } \\
18-24\end{array}$ & $\begin{array}{l}\text { Antibiotic treatment } \\
\text { last } 2 \text { months }\end{array}$ \\
\hline Arvola et al (61) & \begin{tabular}{|l|} 
Ingestion of $L$. rhamnosus \\
GG during antibiotic \\
treatment prevents \\
gastrointestinal side effects
\end{tabular} & $\begin{array}{l}\text { 1) Capsules with } 2 \times 10^{10} \\
\text { CFU L. rhamnosus } \mathrm{GG} \\
\text { twice daily } \\
\text { 2) } \\
\text { Placebo capsules during } \\
\text { antimicrobial treatment }\end{array}$ & RCT & $\begin{array}{l}\text { Children receiving } \\
\text { antibiotics against } \\
\text { respiratory tract } \\
\text { infections } \\
2 \mathrm{w}-13 \text { years of age }\end{array}$ & $\begin{array}{l}\text { 1) Antimicrobial } \\
\text { medication last } 3 \mathrm{~m} \\
\text { 2) Gastrointestinal } \\
\text { disorders } \\
\text { 3) Intravenous } \\
\text { antibiotic treatment }\end{array}$ \\
\hline McFarland et al (62) & \begin{tabular}{|l|} 
Saccharomyces boulardii \\
increases efficacy of \\
treatment with vancomycin \\
or metronidazol to prevent \\
C. difficile recurrence
\end{tabular} & \begin{tabular}{|ll} 
1) & $1 \mathrm{~g} / \mathrm{d}$ of lyophilized \\
& S. boulardii in capsules \\
& $\left(3 \times 10^{10} \mathrm{CFU} / \mathrm{d}\right)$ \\
2) & $\begin{array}{l}\text { Placebo of identical } \\
\text { appearance and odour } \\
\text { (not further specified) }\end{array}$
\end{tabular} & $\begin{array}{l}\text { RCT } \\
\text { Double-blind } \\
\text { Multicenter }\end{array}$ & $\begin{array}{l}\text { C. difficile disease, } \\
\text { ranging from } \\
\text { uncomplicated diarrhoea } \\
\text { to pseudomembranous } \\
\text { colitis. Positive } \\
\text { C. difficile cultures }\end{array}$ & $\begin{array}{l}\text { Inflammatory bowel } \\
\text { disease, AIDS, } \\
\text { cancer } \\
\text { chemotherapy, anti- } \\
\text { fungal therapy, } \\
\text { pregnancy allergy to } \\
\text { vancomycin/ metro- } \\
\text { nidazol, unreliability } \\
\end{array}$ \\
\hline Bennet et al (65) & \begin{tabular}{|l|} 
L. rhamnosus GG prevents \\
relapse of $C$. difficile \\
diarrhoea
\end{tabular} & $\begin{array}{l}\text { 1) } 1,2 \text { or } 4 \text { capsules with } \\
2 \times 10^{10} \mathrm{CFU} \text { L. rhamnosus } \\
\text { GG }\end{array}$ & OT & \begin{tabular}{|l|} 
Outpatients referred \\
because of relapsing \\
C. difficile diarrhoea, or \\
residents at a nursing \\
home with relapsing \\
C. difficile diarrhoea \\
C. diffficile diarrhoea: $>1$ \\
watery stool per day for \\
$>2$ consecutive days \\
+ positive stool culture or \\
toxin test. Relapse: new \\
episode within 4 weeks \\
after treatment \\
\end{tabular} & $\begin{array}{l}\text { Other likely cause } \\
\text { for diarrhoea }\end{array}$ \\
\hline
\end{tabular}


Table 2.Studies on diarrhoea, columns 7-10 (cont).

\begin{tabular}{|c|c|c|c|c|c|c|}
\hline \multirow[t]{2}{*}{ Ref. } & \multirow[t]{2}{*}{ 7. Matching of groups } & \multirow[t]{2}{*}{ 8. Treatment time } & \multirow[t]{2}{*}{ 9. Follow up after treatment } & \multicolumn{3}{|c|}{ 10. Number of subjects/patients } \\
\hline & & & & $\begin{array}{l}\text { Number } \\
\text { starting }\end{array}$ & $\begin{array}{l}\text { Number ending } \\
\text { experimental } \\
\text { period }\end{array}$ & $\begin{array}{l}\text { Number } \\
\text { followed up } \\
\text { (if any) }\end{array}$ \\
\hline 54. & $\begin{array}{l}92 \% \text { had rotavirus in group } 1, \\
74 \% \text { in group } 2 \text { and } 79 \% \text { in } \\
\text { placebo group } \\
\text { Two breastfed infants in groups } 1 \\
\text { and } 3 . \text { Four breast-fed infants in } \\
\text { group } 2\end{array}$ & 5 days & 4 weeks & & & $\begin{array}{ll}\text { 1) } & 24 \\
\text { 2) } & 23 \\
\text { 3) } & 24\end{array}$ \\
\hline 55. & $\begin{array}{l}\text { Study group } 3 \text { months older }(17.5 \\
\text { vs } 14.3 \mathrm{mo}, \mathrm{p}=0.09) \text {. Clinical } \\
\text { picture similar with respect to } \\
\text { weight, dehydration, and } \\
\text { acidosis. }\end{array}$ & 5 days & & & & $\begin{array}{ll}\text { 1) } & 22 \\
\text { 2) } & 17\end{array}$ \\
\hline 56. & $\begin{array}{l}\text { Vomiting more frequent in } \\
\text { placebo group ( } 76 \% \text { ) than } \\
\text { treatment group before start of } \\
\text { the study. Dehydration more } \\
\text { common in } L \text {. reuteri group } \\
\text { (p=0.02). Rotavirus-positive } \\
\text { cultures from } 63 \% \text { of the patients } \\
\text { in the } L . \text { reuteri group compared } \\
\text { with } 86 \% \text { in the placebo group. }\end{array}$ & $\begin{array}{l}\text { Until discharge, } \\
\text { maximally } 5 \text { days }\end{array}$ & $\begin{array}{l}\text { Four weeks after treatment: } \\
\text { rotavirus titres. No difference } \\
\text { between groups }\end{array}$ & $\begin{array}{ll}\text { 1) } & 19 \\
\text { 2) } & 22\end{array}$ & $\begin{array}{l}\text { 1) } 19 \\
\text { 2) } 21 \\
\text { One in placebo } \\
\text { group excluded } \\
\text { because of } \\
\text { presence of } \\
\text { L. reuteri in faeces }\end{array}$ & $?$ \\
\hline 57. & & $\begin{array}{l}\text { Until discharge, } \\
\text { maximally } 5 \text { days }\end{array}$ & & $\begin{array}{l}97 \text { of which } \\
89 \% \text { were } \\
\text { rotavirus } \\
\text { positive }=86 . \\
\text { After exclusion } \\
\text { of those getting } \\
\text { i.v. fluid, } 66 \\
\text { remained } \\
\end{array}$ & $\begin{array}{ll}\text { 1) } & 21 \\
\text { 2) } & 20 \\
\text { 3) } & 25\end{array}$ & \\
\hline 59. & & $21 \mathrm{~d}$ & & $\begin{array}{ll}\text { 1) } & 10 \\
\text { 2) } & 10 \\
\text { 3) } & 10 \\
\end{array}$ & $\begin{array}{ll}\text { 1) } & 9 \\
\text { 2) } & 10 \\
\text { 3) } & 10 \\
\end{array}$ & \\
\hline 60. & & 7 days & & $\begin{array}{l}16 \\
(8+8) \\
\end{array}$ & 16 & \\
\hline 61. & $\begin{array}{l}\text { Age: } 4.7 \text { years }(2 \mathrm{w}-12 \mathrm{y}) \text { in } \mathrm{GG} \\
\text { group, compared to } 4.4 \mathrm{y} \\
(2 \mathrm{w}-13 \mathrm{y}) \text { in control group. }\end{array}$ & $\begin{array}{l}\text { During antimicrobial } \\
\text { therapy }\end{array}$ & & 167 & & 119 \\
\hline 62. & & 4 weeks & $\begin{array}{l}4 \text { weeks } \\
\text { Daily diary for stool frequency } \\
\text { and consistence, other } \\
\text { symptoms and adverse } \\
\text { reactions. Weekly telephone } \\
\text { interviews. } \\
\end{array}$ & 124 & 104 & 95 \\
\hline 65. & & \begin{tabular}{|l|}
10 days (first 12 \\
ambulatory patients) \\
21 days (next 11 \\
patients) \\
14 days (nursing home \\
patients)
\end{tabular} & $\begin{array}{l}1 \text { month (ambulatory patients) } \\
2 \text { months (nursing home } \\
\text { patients }\end{array}$ & $\begin{array}{l}23 \text { ambulatory } \\
(14 \text { women, } \\
9 \text { men) } \\
9 \text { nursing home } \\
(8 \text { women, } \\
1 \text { man) } \\
\end{array}$ & 32 & 32 \\
\hline
\end{tabular}


Table 2.Studies on diarrhoea, columns 11-14 (cont).

\begin{tabular}{|c|c|c|c|c|c|c|c|c|c|}
\hline \multirow[t]{3}{*}{ Ref } & \multicolumn{6}{|c|}{ 11. Results } & \multirow{3}{*}{$\begin{array}{l}\text { 12. } \\
\text { a. Side effects } \\
\text { b. Compliance } \\
\text { measure }\end{array}$} & \multirow{3}{*}{$\begin{array}{l}\text { 13. Evaluation } \\
\text { of quality }\end{array}$} & \multirow{3}{*}{$\begin{array}{l}\text { 14. Concluding remarks } \\
\text { - strength of evidence }\end{array}$} \\
\hline & \multicolumn{2}{|c|}{ Main outcome } & \multicolumn{2}{|c|}{ Other effects } & \multicolumn{2}{|c|}{ Drop-outs } & & & \\
\hline & Treatment & Control & Treatment & Control & $\begin{array}{c}\text { Treat } \\
\text {-ment }\end{array}$ & Control & & & \\
\hline 54. & \multicolumn{2}{|c|}{$\begin{array}{l}\text { Duration of diarrhoea: } \\
\text { 1) } 1.4 \pm 0.8 \text { days } \\
\text { 2) } 1.4 \pm 0.8 \text { days } \\
\text { 3) } 2.4 \pm 1.1 \text { days } \\
\text { (p<0.001, ANOVA) } \\
\text { In rotavirus-positive cases: } \\
\text { 1) } 1.4(0.8) \\
\text { 2) } 1.4(0.9) \\
\text { 3) } 2.7(1.0) \\
\text { (p<0.001, ANOVA) }\end{array}$} & \multicolumn{2}{|c|}{$\begin{array}{l}\text { No difference in vomiting } \\
\text { between groups. No } \\
\text { difference in mannitol } \\
\text { secretion between groups. }\end{array}$} & & & & $++(+)$ & $\begin{array}{l}++(+) \\
\text { Ingestion of milk product } \\
\text { fermented with } \\
\text { L. rhamnosus GG or } \\
\text { freeze-dried bacteria } \\
\text { shortens acute diarrhoea } \\
\text { in children (mainly } \\
\text { rotavirus-induced) }\end{array}$ \\
\hline 55. & $\begin{array}{l}\text { Diarrhoea day 3: } \\
9 \% \\
\text { Duration of } \\
\text { diarrhoea: } \\
1.1 \text { day }\end{array}$ & $\begin{array}{l}53 \% \quad \mathrm{p}=0.002 \\
\\
2.5 \text { days } \\
\mathrm{p}=0.001\end{array}$ & & & & & & $\begin{array}{l}++(+) \\
\text { No data on } \\
\text { breast-feeding }\end{array}$ & $\begin{array}{l}++(+) \\
\text { Intake of milk product } \\
\text { fermented with } \\
\text { L. rhamnosus GG } \\
\text { shortens rotarivus- } \\
\text { induced diarrhoea in } \\
\text { children. } \\
\text { Small effect, but well } \\
\text { proven }\end{array}$ \\
\hline 56. & $\begin{array}{l}\text { Diarrhoea } \\
\text { prevalence: } \\
\text { day 1: } 84 \% \\
\text { day 2: } 26 \% \\
\text { day 3: } 11 \% \\
\text { Mean duration of } \\
\text { diarrhoea shorter } \\
\text { in } L . \text { reuteri group } \\
(\mathrm{p}=0.07)\end{array}$ & $\begin{array}{rl}100 \% & \mathrm{p}=0.06 \\
81 \% & \mathrm{p}<0.001 \\
53 \% & \mathrm{p}<0.01\end{array}$ & $\begin{array}{l}\text { Vomiting } \\
\text { reduced in } \\
\text { L. reuteri } \\
\text { group d } 3 \\
(\mathrm{p}=0.04)\end{array}$ & & & & $\begin{array}{l}\text { Stool cultures } \\
\text { day } 0,2 \text { and at } \\
\text { discharge. } \\
L \text { reuteri } \\
\text { present in } \\
\text { treatment, but } \\
\text { not control } \\
\text { group }\end{array}$ & $\begin{array}{l}++ \\
\text { No data on } \\
\text { breast-feeding } \\
\text { Faeces not } \\
\text { cultured for any } \\
\text { pathogens }\end{array}$ & $\begin{array}{l}++ \\
\text { L. reuteri shortens } \\
\text { duration of acute } \\
\text { diarrhoea in children }\end{array}$ \\
\hline 57. & $\begin{array}{l}\text { Diarrhoea } \\
\text { prevalence day 1: } \\
\text { 1) } 81 \% \text { (p=0.01 } \\
\text { cmp with group 3) } \\
\text { 2) } 100 \% \\
\text { 3) } 100 \% \\
\text { Diarrhoea day 2: } \\
\text { 1) } 48 \%(\mathrm{p}=0.04 \\
\text { cmp with } \\
\text { group 3) } \\
\text { 2) } 70 \% \\
\text { 3) } 80 \%\end{array}$ & & \begin{tabular}{|l|} 
Mean \\
duration of \\
diarrhoea: \\
1) $2.5(1.5) \mathrm{d}$ \\
2) $1.9(0.9) \mathrm{d}$ \\
3) $1.5(1.0) \mathrm{d}$ \\
L. reuteri \\
had sign. \\
effect on \\
duration of \\
diarrhoea \\
(p=0.01, \\
ANOVA) \\
\end{tabular} & & & & $\begin{array}{l}\text { Stool cultures } \\
\text { from } 40 \\
\text { patients. } \\
\text { L. reuteri } \\
\text { counts: } \\
\text { 1) } 10^{48} \\
\mathrm{CFU} / \mathrm{g} \\
\text { 2) } 10^{27} \\
\mathrm{CFU} / \mathrm{g} \\
<10^{1.7} \mathrm{CFU} / \mathrm{g}\end{array}$ & $\begin{array}{l}++(+) \\
\text { No breast- } \\
\text { feeding data }\end{array}$ & $\begin{array}{l}++(+) \\
\text { L. reuteri shortens acute } \\
\text { rotavirus-induced } \\
\text { diarrhoea in children }\end{array}$ \\
\hline 58. & $\begin{array}{l}\text { Stool weight } \\
\text { increase (day } 1-3): \\
98 \mathrm{~g} / \mathrm{d} \\
\text { Abdominal } \\
\text { discomfort: } 1 / 10 \\
\text { Clostridial spores: } \\
1 / 10\end{array}$ & $\begin{array}{l}13 \mathrm{~g} / \mathrm{d} \\
6 / 10 \\
7 / 10\end{array}$ & $\begin{array}{l}\text { Sign. lower } \\
\text { ( } \mathrm{p}=0.025, \\
\text { paired test) } \\
\text { increase in } \\
\text { faecal } \\
\text { weight and } \\
\text { stool } \\
\text { number } \\
\text { during } \\
\text { period with } \\
\text { BA yoghurt } \\
\end{array}$ & & & & & $\begin{array}{l}++ \\
\text { Small study, but } \\
\text { elegant design } \\
\text { and clear-cut } \\
\text { significances }\end{array}$ & $\begin{array}{l}++ \\
\text { Yoghurt with } \\
\text { bifidobacteria reduces } \\
\text { diarrhoea and abdominal } \\
\text { complaints after } \\
\text { erythromycin treatment } \\
++ \\
\text { Significantly ( } \mathrm{p}=0.02, \\
\text { Fisher's exact test) lower } \\
\text { carriage rate of clostridial } \\
\text { spores }\end{array}$ \\
\hline 59. & $\begin{array}{ll}\text { 1) } & 1 / 9 \text { colonized b } \\
\text { 2) } 6 / 10 \quad “ \\
\text { 3) } 6 / 10 \quad \text { “ } \\
\text { 1) } 5 / 9 \text { loose stools } \\
\text { 2) } 6 / 10 \quad \text { “ }, \\
\text { 1) } 2 / 10 \quad \text {, }\end{array}$ & $\begin{array}{l}\text { y } C \text {. difficile } \\
0 / 9 \text { constipated } \\
2 / 10 \\
3 / 10\end{array}$ & & & \begin{tabular}{|l|}
1 in \\
group \\
1, \\
due to \\
treat- \\
ment \\
with \\
other \\
anti- \\
biotics \\
\end{tabular} & & & $\begin{array}{l}++ \\
\text { small study }\end{array}$ & $\begin{array}{l}+ \\
\text { No significant changes in } \\
\text { clinical parameters. } \\
\text { Possible reduction of } \\
\text { C. difficile cololnization } \\
\text { (p=0.08 Fisher's test) }\end{array}$ \\
\hline
\end{tabular}


Table 2.Studies on diarrhoea, columns 11-14 (cont).

\begin{tabular}{|c|c|c|c|c|c|c|c|c|c|c|}
\hline 60. & $\begin{array}{l}\text { Duration of } \\
\text { diarrhoea: } \\
2 \text { days } \\
\text { Stomach pain: } \\
23 \%\end{array}$ & $\begin{array}{l}8 \text { days } \\
39 \%\end{array}$ & $\begin{array}{l}\mathrm{p}<0.05 \\
\mathrm{p}=?\end{array}$ & $\begin{array}{l}\text { Reduced } \\
\text { abdominal } \\
\text { distress, } \\
\text { pain and } \\
\text { flatulence }\end{array}$ & & & & $\begin{array}{l}\text { Blood } \\
\text { concentration } \\
\text { of erythromy- } \\
\text { cin measured } \\
\text { on } 1^{\text {st }} \text { and last } \\
\text { day } \\
\text { Stool samples } \\
1^{\text {st }} \text { and last } \\
\text { days. } L \text {. } \\
\text { rhamnosus GG } \\
\text { identified by } \\
\text { morphology }\end{array}$ & $\begin{array}{l}+(+) \\
\text { Primary data on } \\
\text { diarrhoeal } \\
\text { frequency, } \\
\text { duration not } \\
\text { given in } \\
\text { publication } \\
\text { Small study }\end{array}$ & $\begin{array}{l}+ \\
\text { Reduced diarrhoea in GG } \\
\text { group, but insufficient } \\
\text { data given to judge } \\
\text { strength of conclusion }\end{array}$ \\
\hline 61. & $\begin{array}{l}\text { Diarrhoea }(>2 \\
\text { watery stools/d for } \\
>1 \mathrm{~d}) \\
3(5 \%) \\
\text { No causative agent } \\
\text { found in most } \\
\text { cases of diarrhea }\end{array}$ & $9(16 \%)$ & $\mathrm{p}=0.05$ & $\begin{array}{l}\text { C. difficile- } \\
\text { positive } \\
\text { individuals: } \\
1\end{array}$ & 1 & 28 & 20 & $\begin{array}{l}\text { Faecal cultures } \\
\text { were screened } \\
\text { for } L \text {. } \\
\text { rhamnosus GG } \\
\text { in } 23 \text { randomly } \\
\text { selected } \\
\text { patients. } 21 / 23 \\
\text { had > } 10 \mathrm{e} 3 \\
\text { GFU/g faeces }\end{array}$ & $\begin{array}{l}++ \\
\text { relatively large } \\
\text { study, but large } \\
\text { drop-out rate. No } \\
\text { drop-out analysis }\end{array}$ & $\begin{array}{l}+(+) \\
L . \text { rhamnosus GG } \\
\text { reduces incidence of } \\
\text { antibiotic-associated } \\
\text { diarrhoea. Effect not } \\
\text { quite significant and } \\
\text { large drop-out. }\end{array}$ \\
\hline 62. & $\begin{array}{l}\frac{C . \text { difficile }}{\text { recurrence: }} \\
26.3 \% \\
\text { No of stools/d: } \\
2.1 \\
\text { Toxin B in faeces: } \\
6.7 \% \\
\text { No effect on pain, } \\
\text { nausea, or cramps. }\end{array}$ & $\begin{array}{l}44.8 \% \\
3.3 \\
30 \%\end{array}$ & $\begin{array}{l}\mathrm{p}=0.05 \\
\mathrm{p}=0.02 \\
\mathrm{p}=0.02\end{array}$ & $\begin{array}{l}4 \text { deaths } \\
\text { (S. aureus } \\
\text { sepsis, resp. } \\
\text { arrest, } \\
\text { cardiac } \\
\text { arrest, } \\
\text { prostate } \\
\text { cancer) }\end{array}$ & $\begin{array}{l}1 \text { death } \\
\text { (pneumonia) }\end{array}$ & $\begin{array}{l}\text { Calcu- } \\
\text { lations } \\
\text { based } \\
\text { on } \\
\text { inten- } \\
\text { tion- } \\
\text { to- } \\
\text { treat }\end{array}$ & & $\begin{array}{|ll|}\text { a) } & \text { Increased } \\
& \text { thirst: } \\
& \mathrm{p}=0.02 \\
\text { b) } & \text { Comparison } \\
& \text { of patient } \\
& \text { diary with } \\
& \text { number of } \\
& \text { capsules } \\
& \text { returned by } \\
\text { end of study }\end{array}$ & $\begin{array}{l}+++ \\
\text { Excellent study } \\
\text { Statistics based } \\
\text { on intention-to- } \\
\text { treat. Relapse of } \\
\text { C. difficile } \\
\text { infection strictly } \\
\text { defined and } \\
\text { assessed by three } \\
\text { independent, } \\
\text { blinded observers }\end{array}$ & $\begin{array}{l}+++ \\
\text { Saccharomyces boulardi } \\
\text { potentiated treatment } \\
\text { with vancomycin or } \\
\text { metronidazol in } \\
\text { preventing } C \text {. difficile } \\
\text { recurrence }\end{array}$ \\
\hline 65. & $\begin{array}{l}84 \% \text { did not } \\
\text { relapse during } \\
\text { follow-up period }\end{array}$ & & & & & & & & $\begin{array}{l}++ \\
\text { relatively large } \\
\text { patient group. No } \\
\text { placebo group. }\end{array}$ & $\begin{array}{l}+(+) \\
L . \text { rhamnosus } \text { GG seems } \\
\text { to be effective against } \\
\text { relapsing } C \text {. difficile, but } \\
\text { controlled study needed }\end{array}$ \\
\hline
\end{tabular}

Table 3. Studies in which the effect of fructooligosaccharides on faecal weight in humans has been measured.

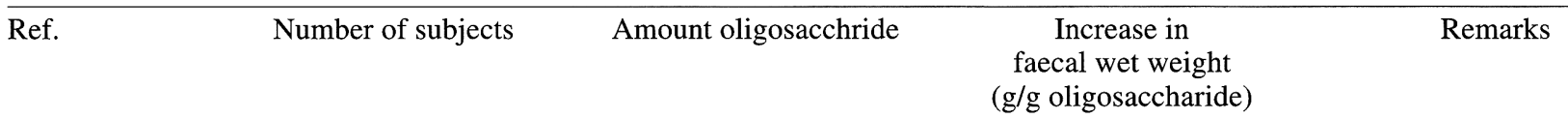

\begin{tabular}{lllll}
\hline Gibson GR et al (45) 8 (7 men, 1 woman) & $\begin{array}{l}15 \text { g oligofructose/day, } \\
4 \text { subjects went on with } \\
\text { another period with inulin } \\
\text { Control sucrose }\end{array}$ & $\begin{array}{l}1.3 \text { for oligofructose } \\
2.0 \text { for inulin }\end{array}$ & $\begin{array}{l}\text { Few subjects, especially } \\
\text { on inulin, no statistical } \\
\text { treatment of faecal weights }\end{array}$ \\
Alles MS et al (46) & $\begin{array}{l}24 \text { healthy men } \\
19-28 \mathrm{y}\end{array}$ & $\begin{array}{l}5-15 \mathrm{~g} / \mathrm{day} \\
\text { No significant effect }\end{array}$ & $\begin{array}{l}\text { Negative result possibly } \\
\text { due to a high fibre intake } \\
\text { (40 g/day) with high } \\
\text { stool output (270 g/day) }\end{array}$ \\
$\begin{array}{l}\text { Castiglia-Delavaud } \\
\text { et al (47) }\end{array}$ & 9 healthy young men & $50 \mathrm{~g} / \mathrm{day}$ & $\begin{array}{l}1.5 \text { for inulin (the same } \\
\text { as for sugar beet fibre) }\end{array}$ &
\end{tabular}


Table 4.Studies on prebiotics and mineral absorbtion, columns 1-14.

\begin{tabular}{|c|c|c|c|c|c|}
\hline 1. Ref & 2. Main hypothesis & 3. Intervention method & 4. Study design & $\begin{array}{l}\text { 5. Recruitment/ } \\
\text { Inclusion criteria }\end{array}$ & 6. Exclusion criteria \\
\hline Coudray et al (90) & $\begin{array}{l}\text { Soulble or partly soluble fibre } \\
\text { improves absorption and } \\
\text { balance of calcium, } \\
\text { magnesium, iron and zink }\end{array}$ & $\begin{array}{l}28 \text { day periods, } 3 \times 3 \text { latin } \\
\text { square design, } 40 \mathrm{~g} \text { inulin } \\
\text { or } 40 \mathrm{~g} \text { sugar beet fibre }+ \\
18 \mathrm{~g} \text { fibre from other } \\
\text { sources per day }\end{array}$ & RCT & 9 male students & $\begin{array}{l}\text { Digestive, hepatic or } \\
\text { cardiac disease }\end{array}$ \\
\hline Van den Heuvel et al (91) & $\begin{array}{l}\text { Inulin, fructooligosaccharides } \\
\text { and galactooligosaccharides } \\
\text { increase mineral absorption }\end{array}$ & $4 \times 21$ days & RCT & $\begin{array}{l}12 \text { healthy male subjects } \\
20-30 \mathrm{y} \\
\text { Typical Dutch food pattern }\end{array}$ & Any health problem \\
\hline Van den Heuvel et al (92) & $\begin{array}{l}\text { Moderate dose of oligofructose } \\
\text { stimulates calcium absorption } \\
\text { in adolescents }\end{array}$ & $2 \times 9$ days & RCT, double-blind & 12 boys $14-16$ & \\
\hline
\end{tabular}

\begin{tabular}{|c|c|c|c|c|c|c|}
\hline \multirow[t]{2}{*}{ Ref. } & \multirow[t]{2}{*}{ 7. Matching of groups } & \multirow[t]{2}{*}{ 8. Treatment time } & \multirow{2}{*}{$\begin{array}{l}\text { 9. Follow up after treatment } \\
\text { (if any, e.g. persistens of } \\
\text { probiotic organism in faeces, } \\
\text { recurrence of symptoms) }\end{array}$} & \multicolumn{3}{|c|}{ 10. Number of subjects/patients } \\
\hline & & & & Number starting & $\begin{array}{l}\text { Number ending } \\
\text { experimental } \\
\text { period }\end{array}$ & $\begin{array}{l}\text { Number } \\
\text { followed up } \\
\text { (if any) }\end{array}$ \\
\hline 90. & Own controls & $\begin{array}{l}28 \text { days ( } 12 \text { with } \\
\text { maximum fibre intake) }\end{array}$ & No & 9 & 9 & \\
\hline 91. & Own control & $\begin{array}{l}21 \text { days } \\
\text { Iron absorption measured } \\
\text { last } 7 \text { days, calcium } \\
\text { absorption measured last } \\
\text { day }\end{array}$ & No & 12 & 12 & \\
\hline 92. & Own control & $\begin{array}{l}2+7 \text { days treatment } \\
\text { periods }\end{array}$ & No & 12 & 12 & \\
\hline
\end{tabular}

\begin{tabular}{|c|c|c|c|c|}
\hline Ref & $\begin{array}{l}\text { 11. Results } \\
\text { Main outcome } \\
\text { Treatment }\end{array}$ & $\begin{array}{l}\text { 12. } \\
\text { a. Side effects } \\
\text { b. Compliance } \\
\text { measure }\end{array}$ & $\begin{array}{l}\text { 13. Evaluation } \\
\text { of quality }\end{array}$ & 14. Concluding remarks - strength of evidence \\
\hline 90. & $\begin{array}{l}\text { Inulin increased apparent } \mathrm{Ca} \text { absorption by } 58 \% \text {. } \\
\text { Both beet fibre and inulin increased absolute } \\
\text { absorption. Apparent balance also positive. } \\
\text { No effect on } \mathrm{Mg}, \mathrm{Fe} \text { or } \mathrm{Zn}\end{array}$ & No reported & ++ & $\begin{array}{l}\text { Increased calcium apparent absorption by inulin using } \\
\text { conventional balance technique. Balance periods short } \\
\text { for calcium. }\end{array}$ \\
\hline 91. & $\begin{array}{l}15 \mathrm{~g} \text { inulin, oligofructose or galactooligo- } \\
\text { saccharides/day did not alter Ca or Fe absorption } \\
\text { ( } 7 \text { days measurement of iron, } 24 \mathrm{~h} \text { measurement of } \mathrm{Ca} \text { ) }\end{array}$ & No reported & ++ & $\begin{array}{l}\text { No effect, probably related to short measurement } \\
\text { period for calcium (24h). } \\
\text { One ileostomy study (Ellegård et al (38)) support no } \\
\text { effect of inulin on the level of small intestine }\end{array}$ \\
\hline 92. & $\begin{array}{l}15 \mathrm{~g} \text { oligofructose/day increased fractional } \mathrm{Ca} \\
\text { absorption from } 48 \text { to } 60 \% \text { during } 36 \mathrm{~h}\end{array}$ & No reported & ++ & $\begin{array}{l}\text { Increased calcium absorption after } 36 \mathrm{~h} \text {, allowing for } \\
\text { effects on colonic absorption. } \\
\text { Isotope technique }\end{array}$ \\
\hline
\end{tabular}

